\title{
Characterization of the physical, microbiological, and chemical properties of sonicated raw bovine milk
}

\author{
D. L. Van Hekken, J. Renye Jr., A. J. Bucci, ${ }^{*}$ and P. M. Tomasula† \\ Dairy \& Functional Foods Research Unit, Eastern Regional Research Center, Agricultural Research Service, USDA, Wyndmoor, PA 19038
}

\begin{abstract}
Innovative processing technologies, such as ultrasonication, can change the properties of milk, allowing for the improvement or development of dairy foods. Yet taking bench-scale equipment to pilot plant scale has been challenging. Raw milk, standardized to $3 \%$ fat and warmed to inlet temperatures of 42 or $54^{\circ} \mathrm{C}$, was exposed to continuous, high-intensity, low-frequency ultrasonication $(16 / 20 \mathrm{kHz}, 1.36 \mathrm{~kW} /$ pass $)$ at flow rates of $0.15,0.30$, and $0.45 \mathrm{~L} / \mathrm{min}$ that resulted in resident times within the reaction cell of 6,3 , and 2 min per pass, respectively. Multiple passes (3, 5 , and 7 , respectively) were required to obtain a total exposure time of 14 to 18 min. Evaluation of fat droplet sizes, enzyme coagulation properties, and microstructure of milk and milk gels, as well as determining compositional and lipid properties, were conducted to determine the potential of the ultrasound system to effectively modify milk. Laser scanning particle sizing and confocal microscopy showed that the largest droplets $(2.26 \pm 0.13 \mu \mathrm{m})$ found in raw milk were selectively reduced in size with a concomitant increase in the number of submicron droplets $(0.37 \pm 0.06 \mu \mathrm{m})$, which occurred sooner when exposed to shorter bursts of ultrasonication $(0.45 \mathrm{~L} / \mathrm{min}$ flow rates) and at an inlet temperature of $54^{\circ} \mathrm{C}$. Ultrasound processing with milk entering at $42^{\circ} \mathrm{C}$ resulted in faster gelling times and firmer curds at $30 \mathrm{~min}$; however, extended processing at inlet temperature of $54^{\circ} \mathrm{C}$ reduced curd firmness and lengthened coagulation time. This showed that ultrasonication altered protein-protein and protein-lipid interactions, thus the strength of the enzyme-set curds. Scanning electron microscopy revealed a denser curd matrix with less continuous and more irregular shaped and clustered strands, whereas transmission electron microscopy showed submicron lipid droplets embedded
\end{abstract}

\footnotetext{
Received September 30, 2018.

Accepted December 23, 2018.

*Current affiliation: West Pharmaceutical Services Inc., Exton, PA

†Corresponding author: Peggy.Tomasula@ARS.USDA.gov
} 19341. within the protein strands of the curd matrix. Processing at inlet temperature of $54^{\circ} \mathrm{C}$ with flow rates of 0.30 and $0.45 \mathrm{~L} / \mathrm{min}$ also reduced the total aerobic bacterial count by more than $1 \log \mathrm{cfu} / \mathrm{mL}$, and the number of psychrophiles below the limit of detection $(10 \mathrm{cfu} / \mathrm{mL})$ for this study. Ultrasonication exposures of 14 to 18 min had minimal effect on the milk composition, fatty acid profiles, and lipid heat capacity and enthalpy. The findings show that this continuous ultrasound system, which is conducive to commercial scale-up, modifies the physical and functional properties of milk under the parameters used in this study and has potential use in dairy processing.

Key words: raw milk, ultra-sonication, fat droplet size, coagulation, homogenization

\section{INTRODUCTION}

Innovative nonthermal processing technologies, such as ultrasonication (US), alter the properties of milk, allowing for the production of novel-textured, high-moisture dairy foods. Application of US in dairy processing is a relatively young field of study. Processing at high frequencies $(>1,000 \mathrm{kHz})$, a nondestructive range of US, has been shown to separate milk fat into fractions containing different-sized droplets (Leong et al., 2014, 2016) and improve the creaming properties of recombined milk (Juliano et al., 2011). Studies using low frequencies (20 to $40 \mathrm{kHz}$ ) have reported that US improved the degassing of skim milk (Villamiel et al., 2000), the heat stability of whey proteins (Ashokkumar et al., 2010), the solubility of concentrated milk (Zisu et al., 2013; Yanjun et al., 2014), and ice cream production and quality (Mortazavi and Tabatabaie, 2008). Ultrasonication was also reported to be effective in reducing bacterial populations (Feng et al., 2008; Drakopoulou et al., 2009), including pathogens and spoilage bacteria in milk (Villamiel and De Jong, 2000b; Cameron et al., 2009; Chouliara et al., 2010).

The majority of food processing applications have been conducted between frequencies of 20 to 1,000 $\mathrm{kHz}$, a range where micro bubbles form, pulse, expand (usually in the $<100 \mu \mathrm{m}$ range), and collapse within 
microseconds. The strongest acoustic cavitation effects are created at low frequencies $(20$ to $40 \mathrm{kHz})$ and high intensity (10 to $1,000 \mathrm{~W}$ ) and result in microenvironments of high temperatures and pressures, turbulence, and shear throughout a liquid sample that permanently alters the physical and chemical properties of the food (Ashokkumar et al., 2010; Gallego-Juárez and Graff, 2015; Zisu and Chandrapala, 2015). As frequencies increase, the bubbles collapse sooner and with smaller radii so the cavitation effect is less.

The homogenizing property of US is well established, although comparisons among the array of different systems and processing conditions can be difficult. With sufficient power (usually 20 to $24 \mathrm{kHz}$ and $50 \mathrm{~W}$ to 1 $\mathrm{kW}$ ) and exposure time (10 to $120 \mathrm{~min}$ ), US can reduce the wide range of lipid droplet sizes found in raw milk to a narrow band of submicron-sized droplets (Wu et al., 2001; Shanmugam et al., 2012). Thermosonication, which is US conducted at higher temperatures (usually above $55^{\circ} \mathrm{C}$ for dairy processing), improved the efficiency of the US treatments by shortening the time for these changes to occur (Ertugay et al., 2004; Riener et al., 2009, 2010). Ultrasonication of milk also improved its coagulation properties by decreasing the time to onset of gelation and increasing the curd firmness in whole (Marchesini et al., 2012) and skim milk (Nguyen and Anema, 2010; Liu et al., 2014). These findings demonstrate that US affected both the lipids and proteins found in milk. Ultrasonication has been reported to improve the water-holding capacity, increase curd firmness, and decrease syneresis in yogurt ( $\mathrm{Wu}$ et al., 2001; Riener et al., 2009, 2010; Zisu et al., 2011).

The majority of studies using US technology to homogenize milk and milk products have been conducted at the bench-scale using US transducers submerged in small volumes of liquid. Larger, continuous US systems operating at 20 or $35 \mathrm{kHz}, 150 \mathrm{~W}$ to $4 \mathrm{~kW}$, and flow rates 0.01 to $6 \mathrm{~L} / \mathrm{min}$ have reduced lipid droplets to submicron sizes while successfully inactivating milk enzymes (Villamiel and De Jong, 2000a), decreased the viscosity of whey protein and calcium caseinate solutions (Zisu et al., 2010), and reduced bacterial counts (Crudo et al., 2014). More research is needed on large-scale, continuous US systems as new concepts are incorporated into their design.

In this study, a continuous US system with dual-frequency transducers in a parallel plate configuration was employed. The system is an indirect system that does not allow direct contact between the milk and the US transducers, efficiently chills the reaction chamber to prevent heat exposure, and results in shorter processing times to achieve the desired US exposure treatments. The objectives of this study are to characterize the ef- fects of continuous US technology, in combination with various inlet temperatures, flow rates, and total exposure times, on the chemical, physical, and chymosincoagulation properties of raw milk and determine its suitability for altering the properties of milk.

\section{MATERIALS AND METHODS}

\section{Processing}

Milk. Raw milk (75 kg/shipment) was obtained from a local dairy farm. A portion of the farm milk was skimmed (F15 Disc Bowl centrifuge; Armfield Inc., Clarksburg, NJ) and used to dilute the farm milk to $3.0 \%$ fat. The standardized milk was stored in 5-L cans at $1.8^{\circ} \mathrm{C}$ until undergoing US processing. To optimize personnel and equipment usage, US was conducted on the 2nd and 3rd day; 2 US treatments were conducted per milk shipment. Before processing, a 1-L sample was removed from the can and used as a nonprocessed control.

Ultrasound Processing. The assembled system (Figure 1) consisted of a HTST/UHT heat exchanger/ pump (FT74XTS, Armfield Limited, Ringwood, UK) that was used to heat and control the flow rate of milk to the US system. This was followed by a continuous US unit (DRC-8-DPP-FGS, Advanced Sonic Processing Systems, Oxford, CT) with a $2.4 \mathrm{~kW}$ dual-frequency reactor cell (parallel diaphragm plates) with 2 low-frequency (16 and $20 \mathrm{kHz}$, nominal 1,200 W each) transducers housed within a cooling jacket. The transducers were configured to eliminate standing waves, set at a maximum acoustic intensity of $100 \mathrm{~W} / \mathrm{cm}^{3}$, and delivered $1.36 \mathrm{~kW}$ per pass. The acoustic cavity or reactor was cylindrical in shape and contained the 2 diaphragm stainless steel plates (diameter of $20.3 \mathrm{~cm}$ ), separated by a $3.2-\mathrm{cm}$ spacer. The reactor volume given by the manufacturer is $0.865 \mathrm{~L}$. Milk entered the reaction cell through $20.3 \mathrm{~cm}$ of a $0.75 "(1.9 \mathrm{~cm})$ sanitary stainless steel pipe in the chilled transducer section, then entered the reactor through the side of the bottom of the $20-\mathrm{kHz}$ transducer plate, flowed through the space between the plates, out the top of the second plate, and then through the $16-\mathrm{kHz}$ chilled section, through a pipe with the same dimensions as the inlet pipe, and exited the system (flowing directly into the small-mouth collection container). Circulating water at $10^{\circ} \mathrm{C}$ was used to cool the transducers via the cooling jacket. Milk was warmed using the Armfield unit. After preliminary trials, the inlet temperatures of 42 or $54^{\circ} \mathrm{C}$ were chosen, a range in which milk entered the US chamber just above the melting point of milk fat $\left(>40^{\circ} \mathrm{C}\right)$ or just below the temperature generally considered the start for thermo- 
sonication $\left(>55^{\circ} \mathrm{C}\right)$. Although temperatures increased within the reaction cell during US, the cooling jacket reduced samples to exit temperatures ranging from 20 to $30^{\circ} \mathrm{C}$. Milk was pumped into the US system at 3 different flow rates; the slowest $(\mathbf{s})$ was at $0.15 \mathrm{~L} / \mathrm{min}$, the medium $(\mathbf{m})$ was at $0.30 \mathrm{~L} / \mathrm{min}$; and the fastest (f) was at $0.45 \mathrm{~L} / \mathrm{min}$. The residence time $(\mathbf{t})$ for a single pass through the reactor is given by $\mathrm{t}=$ volume of the reactor/flow rate. For the 3 flow rates above, the values of t are 6, 3, and 2 min, respectively. Several passes were used to obtain total residence times within the US reaction cell of around $15 \mathrm{~min}$. The s flow rate required 3 passes and resulted in $\mathrm{t}$ of 6,12 , and $18 \mathrm{~min}$. The $\mathrm{m}$ flow rate needed 5 passes for $\mathrm{t}$ of $3,6,9,12$, and $15 \mathrm{~min}$. The $\mathrm{f}$ flow rate required 7 passes to obtain $\mathrm{t}$ of $2,4,6$, $8,10,12$, and 14 min. Following each pass through the US system, milk was collected and stored on ice before reheating to the desired inlet temperature. Samples for analyses were collected from each pass, exit temperatures were recorded, and samples to be assayed were immediately refrigerated at $1.8^{\circ} \mathrm{C}$. Individual samples were identified according to inlet temperature $\left({ }^{\circ} \mathrm{C}\right)$, flow rate ( $\mathrm{s}, \mathrm{m}$, or $\mathrm{f})$, and total US residence time (min). For example, milk that entered the US chamber at $42^{\circ} \mathrm{C}$ at the slowest flow rate, and underwent 2 passes would be identified as $42 \mathrm{~s} 12\left({ }^{\circ} \mathrm{C}\right.$, flow rate, $\left.\min \right)$.

\section{Physical Properties}

Fat Droplet Size. Particle size was measured in triplicate for all milk samples $24 \mathrm{~h}$ after US processing using a laser scanning particle size distribution analyzer (Partica LA-950V2, Horiba Instruments, Kyoto, Japan). The volume-weighted $(\mathrm{d}[4,3])$ and area-weighted $(\mathrm{d}[3,2])$ droplet sizes were calculated using a refractive index of 1.38 .

Milk Imaging. Confocal microscopy was conducted as described by Tunick et al. (2016). Briefly, fresh samples $(0.18 \mathrm{~mL})$ were fixed with $0.02 \mathrm{~mL}$ of $25 \%$ glutaraldehyde (Electron Microscopy Sciences, Hatfield, PA), stained with $0.01 \%$ Fast Green FCF (protein) and $0.01 \%$ Nile Red (lipids), and examined using a confocal laser scanning microscope (TCS SPE, Leica Microsystems, Buffalo Grove, IL) at $100 \times$ magnification.

Coagulation Assays. The viscoelastic properties of coagulating milk were tracked using a small amplitude oscillatory shear analyzer (Kinexus Lab Plus Rheometer, Malvern Instruments, Westborough, MA) fitted with a cup-and-bob attachment (PC25C019AL and C25 SW1399 SS, respectively). A strain sweep was conducted on $17.0 \mathrm{~mL}$ of milk at $25^{\circ} \mathrm{C}$ to determine the linear range. Enzyme coagulation properties were determined as described by Bucci et al. (2018). An ali-

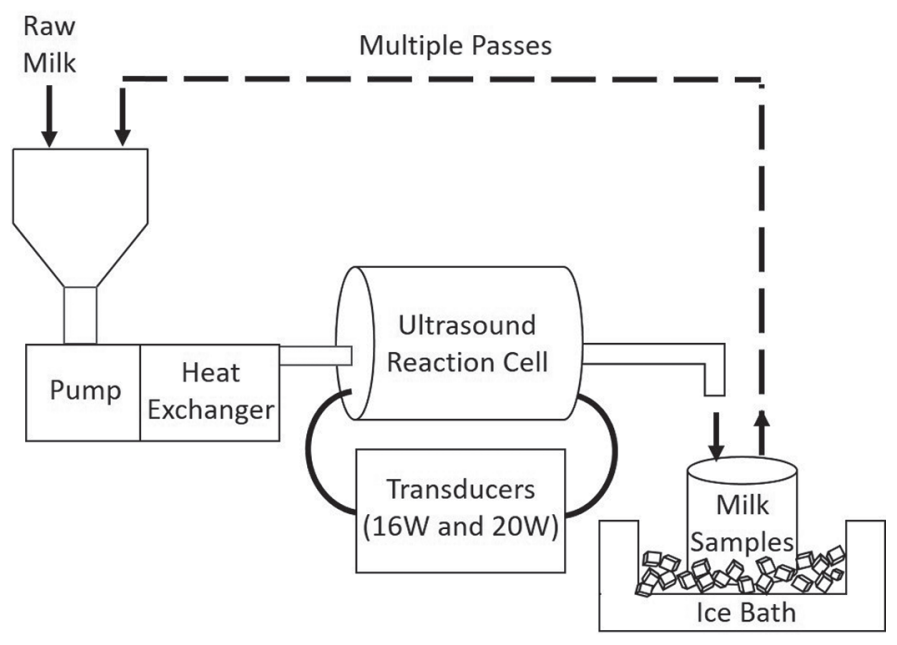

Figure 1. Diagram of ultrasonication system.

quot $(17.0 \mathrm{~mL})$ of sample was warmed to $35^{\circ} \mathrm{C}$ in the cup before the addition of a $0.395-\mathrm{mL}$ chymosin solution (2.00 g of Chy-Max in 100-mL water; Chr. Hansen, Milwaukee, WI). The bob was lowered into place, and time sweeps were conducted in duplicate at $35^{\circ} \mathrm{C}, 10$ $\mathrm{Hz}$, and $0.015 \%$ strain. Coagulation time (when elastic modulus, $\mathrm{G}^{\prime}$, began to rise) and curd firmness $\left(\mathrm{G}^{\prime}\right.$ at 30 min after enzyme addition) were recorded.

Milk Gel Imaging. Milk gel imaging was performed within $12 \mathrm{~h}$ of coagulation assays. Milk samples (10 $\mathrm{mL}$ ) were warmed to $35^{\circ} \mathrm{C}$ before addition of the chymosin solution $(0.1 \mathrm{~mL})$; swirled gently and capped with parafilm; and incubated at $35^{\circ} \mathrm{C}$ for $30 \mathrm{~min}$. A portion of the gel was immediately submerged in $2.5 \%$ glutaraldehyde for $30 \mathrm{~min}$, cut into 3 - to $5-\mathrm{mm}^{3}$ pieces, and stored at $4^{\circ} \mathrm{C}$ until processed for scanning electron microscopy and transmission electron microscopy (TEM). Samples were washed in $0.01 M$ imidazole (Electron Microscopy Sciences), dehydrated through series of washes with increasing ethanol concentrations, critical point dried (Denton Vacuum, Cherry Hill, NJ), and mounted on stubs and gold-coated (150R ES, Electron Microscopy Sciences) for scanning electron microscopy (FEI Quanta 200 F SEM, Hillsboro, OR) imaging. Samples for TEM were washed in imidazole, stained with $1 \%$ osmium tetroxide (Electron Microscopy Sciences), dehydrated in ethanol washes, rinsed with propylene oxide (Electron Microscopy Sciences), infiltrated with an increasing series of resin (LX-112, Ladd Research, Williston, VT), and cured overnight in a vacuum oven at $60^{\circ} \mathrm{C}$. Thin sections were prepared using a diamond knife (Diatome, Hatfield, PA) and then stained in uranyl acetate, then lead citrate (Electron Microscopy Sciences) for TEM (CM 12, Philips, Amsterdam, the Netherlands) imaging. 


\section{Microbiological and Chemical Properties}

Microbiology. Milk samples were collected aseptically into sterile $15-\mathrm{mL}$ tubes at the US outlet port and stored at $4^{\circ} \mathrm{C}$ for up to $3 \mathrm{~h}$ before plating. Serial dilutions were prepared using $0.1 \%$ peptone water, with $0.1 \mathrm{~mL}$ of each dilution dispersed in duplicate on plate count agar (Oxoid Limited, Basingstoke, UK). Total aerobic counts were determined following incubation at $32^{\circ} \mathrm{C}$ for $48 \mathrm{~h}$, and psychrophilic counts were determined after incubation at 4 to $6^{\circ} \mathrm{C}$ for $10 \mathrm{~d}$. Bacterial counts were reported as the mean $\log _{10}$ colony-forming units per milliliter ( \pm standard deviation) from a minimum of 2 independent processing runs.

Milk Composition. The moisture, fat, protein, and lactose contents of milk were measured in triplicate at the time of US processing, using a mid-range infrared milk analyzer (Milkoscan Minor 6, FOSS North America Ltd., Chicago, IL; method 972.16; AOAC International, 2012). All samples were tested in duplicate for alkaline phosphatase activity (PAS-Lite, Charm Sci. Inc., Lawrence, MA).

Fat Properties. Fresh, non-processed control milk and milk US treated at the maximum 18-min exposure were centrifuged (Advanti J-301, Beckman Coulter, Indianapolis, IN) at $4^{\circ} \mathrm{C}$ for $30 \mathrm{~min}$ at $10,000 \times g$ and the top fat layer was collected. Fatty acid profiles were obtained using a modified FAME method based on Tunick and Van Hekken (2017). Briefly, triglycerides from approximately $23 \mathrm{mg}$ of milk fat were dissolved in hexanes (Fisher Scientific, Fair Lawn, NJ) and converted to methyl esters using sodium methoxide (Sigma Aldrich, St. Louis, MO); water was removed using $\mathrm{CaCl}_{2}$ (Fisher Scientific). Particles were removed by centrifugation $\left(700 \times g\right.$ for $3 \mathrm{~min}$ at $\left.22^{\circ} \mathrm{C}\right)$, and triplicate $1-\mu \mathrm{L}$ samples in hexane were analyzed by a gas chromatograph (Trace 1300, Thermo Fisher Scientific, Waltham, MA) fitted with a CP-Sil 88 column (100 m $\times 0.25$; Agilent Technologies, Wilmington, DE) and a flame ionization detector set at $270^{\circ} \mathrm{C}$. The Chromeleon Chromatography Data System (Dionex, Thermo Fisher Scientific) was used for instrument operation and data analysis. Separation began at $80^{\circ} \mathrm{C}$ and increased by $4^{\circ} \mathrm{C} / \mathrm{min}$. Following a $5 \mathrm{~min}$ hold at $220^{\circ} \mathrm{C}$, the temperature was further increased by $4^{\circ} \mathrm{C} / \mathrm{min}$ to $240^{\circ} \mathrm{C}$, and held for $10 \mathrm{~min}$. Peaks calculated as percentage of fatty acids were identified using references for standard carbon 4 to 24 methyl esters and conjugated methyl linoleate (448 and 678; Nu-Chek Prep, Elysian, MN).

Differential Scanning Calorimetry. Melt properties of US milk fat were evaluated in triplicate using the methodology described by Tunick and Malin (1997). Briefly, 12-mg samples of thawed milk fat were warmed to $90^{\circ} \mathrm{C}$ for $2 \mathrm{~h}$ and stored in a desiccator at $22^{\circ} \mathrm{C}$. Melt profiles of each sample were collected using a differential scanning calorimetry (DSC) unit (DSC Q100, TA Instruments, New Castle, DE) that tempered the sample at $50^{\circ} \mathrm{C}$ for $5 \mathrm{~min}$, then lowered it by $5^{\circ} \mathrm{C} /$ min to $-50^{\circ} \mathrm{C}$ to equilibrate for $5 \mathrm{~min}$, and finally raised the temperature by $5^{\circ} \mathrm{C} / \mathrm{min}$ to $50^{\circ} \mathrm{C}$. Instrument software (Universal Analysis 2000, version 4.7A; TA Instruments) was used to integrate profiles and calculate temperature and enthalpy of melt.

\section{Statistics}

Processing runs were executed over a 10 -wk period with 1 or 2 random processing treatments conducted each week; all treatments were performed in triplicate. Data analysis for particle size, coagulation time, curd firmness, composition, fatty acid profiles, and melt properties were conducted using ANOVA; a PROC MIXED statement (Version 9.4 SAS-STAT, SAS Institute Inc., Cary, NC). The inlet temperature and accumulated exposure time were the fixed variables and replication of the treatments (rep) was the random factor. The Bonferroni least significant difference test was used to determine significant differences $(P<0.05)$.

\section{RESULTS AND DISCUSSION}

\section{Processing}

Ultrasonication processing details are summarized in Table 1. Flow rates were reduced to maximize US exposure times per pass. Although processing runs lasted about $2 \mathrm{~h}$ to obtain 14 to $18 \mathrm{~min}$ of actual US exposure; for most of that 2-h period, the samples were stored on ice waiting for the next pass. Actual processing time can be reduced, and yield increased by placing multiple continuous US units in series but was out of the scope of this study. Another benefit to a continuous system is that the transducers are never in direct contact with the milk, thus improving food safety and the ability to clean in place.

Because the transducers are surrounded by cooling medium, the surface of the diaphragm plates remained at or near the temperature of the medium. This was measured indirectly by determining the increase in temperature of the cooling water that exited the jacket with or without fluid in the reaction cell. A nominal increase to the exiting cooling water temperature of no more than $2^{\circ} \mathrm{C}$ was observed without fluid in the reaction cell, with no additional increase detected when milk flowed through the system at any of the 3 flow rates tested. However, a significant net cooling effect on 
Table 1. Processing details for ultrasonication of raw milk including circulation information and temperatures (means and SD) entering (inlet) and exiting after the last pass (outlet) the ultrasonication system ${ }^{1}$

\begin{tabular}{|c|c|c|c|c|}
\hline \multirow[b]{2}{*}{ Processing property } & & \multicolumn{3}{|c|}{ Flow rate } \\
\hline & & $0.15 \mathrm{~L} / \mathrm{min}$ & $0.30 \mathrm{~L} / \mathrm{min}$ & $0.45 \mathrm{~L} / \mathrm{min}$ \\
\hline \multicolumn{5}{|l|}{ Circulation details } \\
\hline Exposure time per pass (min) & & 6 & 3 & 2 \\
\hline Passes conducted & & 3 & 5 & 7 \\
\hline Passage through system (min) & & $9.4 \pm 1.6$ & $5.6 \pm 0.5$ & $4.1 \pm 0.3$ \\
\hline \multirow[t]{2}{*}{ Total processing $(\mathrm{min})$} & & $133 \pm 27.4$ & $129 \pm 7.5$ & $124 \pm 20.9$ \\
\hline & Inlet & \multicolumn{3}{|c|}{ Outlet } \\
\hline Temperature $\left({ }^{\circ} \mathrm{C}\right)$ & 42 & $19.5 \pm 2.3$ & $21.9 \pm 2.0$ & $24.8 \pm 1.3$ \\
\hline & 54 & $24.1 \pm 0.8$ & $28.3 \pm 0.8$ & $31.4 \pm 0.4$ \\
\hline
\end{tabular}

${ }^{1}$ Treatments were conducted at 2 inlet temperatures and 3 flow rates.

the milk passing through the reaction cell was observed, decreasing the temperature by 16.4 to $29.1^{\circ} \mathrm{C}$ linearly with increasing flow rate. Samples exiting the system were below $40^{\circ} \mathrm{C}$, a temperature where most fats in milk are not in the liquid state and not as susceptible to US penetration (Earnshaw et al., 1995).

Although US is considered a nonthermal process, Nguyen and Anema (2010) reported that without any control, temperature increased from 20 to $>80^{\circ} \mathrm{C}$ within $5 \mathrm{~min}$ for $18 \mathrm{~mL}$ of skim milk when ultrasonicated at $22.5 \mathrm{kHz}$ and $50 \mathrm{~W}$, well above pasteurization conditions and into the range of whey protein denaturation. Although thermosonication has a synergistic effect, temperature control is essential to manage the desired US outcome. The use of water at $10^{\circ} \mathrm{C}$ to cool the US reaction cell demonstrated the efficiency of the system to mitigate any heat generated within the reaction cell, and adjustments to the temperature of this cooling water should establish any US conditions required.

Information on continuous US systems is still very limited. Villamiel and De Jong (2000a) reported that a continuous system centered on a transducer in direct contact with the sample operating at $20 \mathrm{kHz}$ and 150 $\mathrm{W}$ with flow rates of 0.011 to $0.028 \mathrm{~L} / \mathrm{min}$ inactivated milk enzymes after $102 \mathrm{~s}$ exposure at $75^{\circ} \mathrm{C}$. Zisu et al. (2010) reported that a continuous system using a horn operating at $20 \mathrm{kHz}$ and 1 to $4 \mathrm{~kW}$ with flow rates of 0.2 to $6.0 \mathrm{~L} / \mathrm{min}$ decreased the viscosity of whey and casein ingredient solutions and improved the coagulation traits. Crudo et al. (2014) reported that a continuous system operating at $35 \mathrm{kHz}$ and $370 \mathrm{~W}(1194$ $\mathrm{W} / \mathrm{L}$ ) with a flow rate of $0.17 \mathrm{~L} / \mathrm{min}$ reduced bacterial counts by $95 \%$ after a 10 min exposure at $37^{\circ} \mathrm{C}$. Our continuous system with a $2.4 \mathrm{~kW}$ reactor cell, delivering $1.36 \mathrm{~kW}$ per pass, and a parallel plate configuration of 2 transducers $(16 / 20 \mathrm{kHz})$, compares well with these systems although further optimization of flow rates, ex- posure times, and temperatures are required to obtain a homogeneous submicron emulsion.

\section{Physical Properties}

Fat Droplet Properties. As expected, the typical wide distribution of fat droplet sizes in raw nonhomogenized 3\% milk was altered when exposed to US treatments at different temperatures and increasing exposure times. The d[4,3] profiles (Figure 2), which were volume-weighted and more sensitive to larger particles, showed a single, broad-based peak with a mode diameter of $2.26 \pm 0.13 \mu \mathrm{m}$ for the raw milk controls. Ultrasonication processing of milk with inlet temperatures at $42^{\circ} \mathrm{C}$ (Figure 2a, 2c, 2e) resulted in a narrower peak, with decreased distribution, as the averaged diameter shifted slightly to $2.10,2.08$, and 1.91 $\mu \mathrm{m}$ for the slowest, medium, and fastest flow rates, respectively. A second narrow peak with a mode diameter of $0.37 \pm 0.06 \mu \mathrm{m}$ appeared after total US exposures of 18,12 , and $8 \mathrm{~min}$ for the slowest, medium, and fastest flow rates, respectively. Overall, results showed that shorter exposure times with more passes led to greater reductions in particle size. When milk with the inlet temperature of $54^{\circ} \mathrm{C}$ was ultrasonicated (Figure 2b, 2d, 2f), mode diameters decreased by $0.28,0.54$, and 0.64 $\mu \mathrm{m}$ after exposures of 18,15 , and $14 \mathrm{~min}$ at the slowest, medium, and fastest flow rates, respectively, with only slight decreases in distribution. The submicron peak also appeared earlier, after 12, 9, and $6 \mathrm{~min}$ at the slowest, medium, and fastest flow rates, respectively.

The d[3,2] profiles (Figure 3), which were area (surface)-weighted and more sensitive to smaller particles, reflected changes in the distribution of the smaller fat droplets. Only slight differences $(<0.02 \mu \mathrm{m})$ in the main peak diameters were noted when milk at $42^{\circ} \mathrm{C}$ inlet temperature was ultra-sonicated (Figure 3a, 3c, 
a)

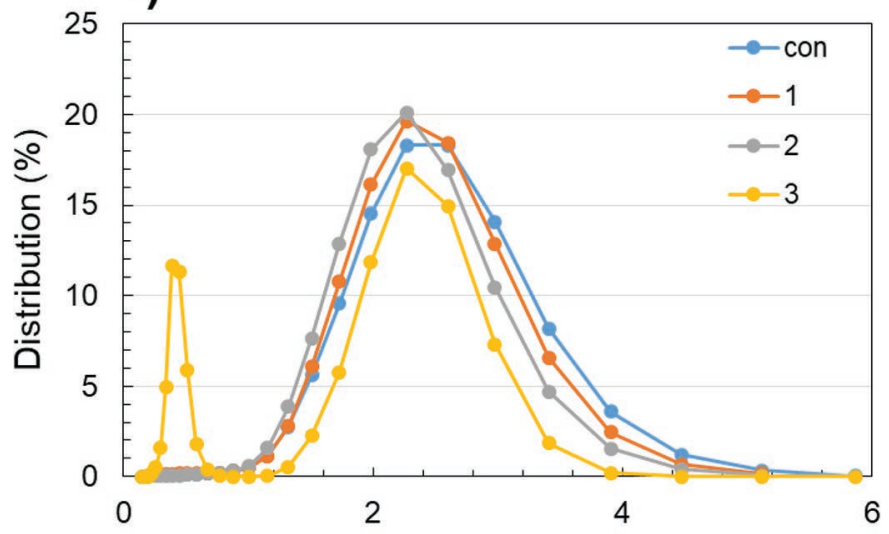

c)

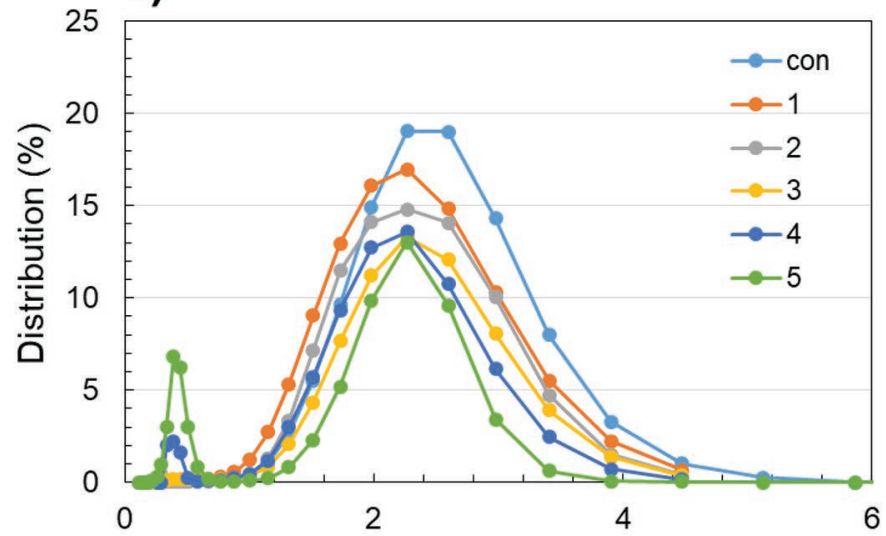

e)

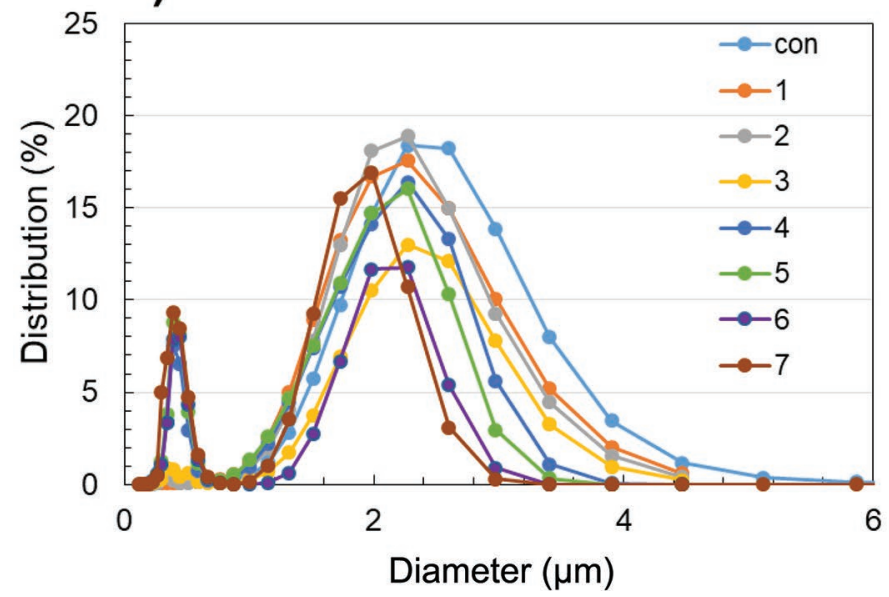

b)

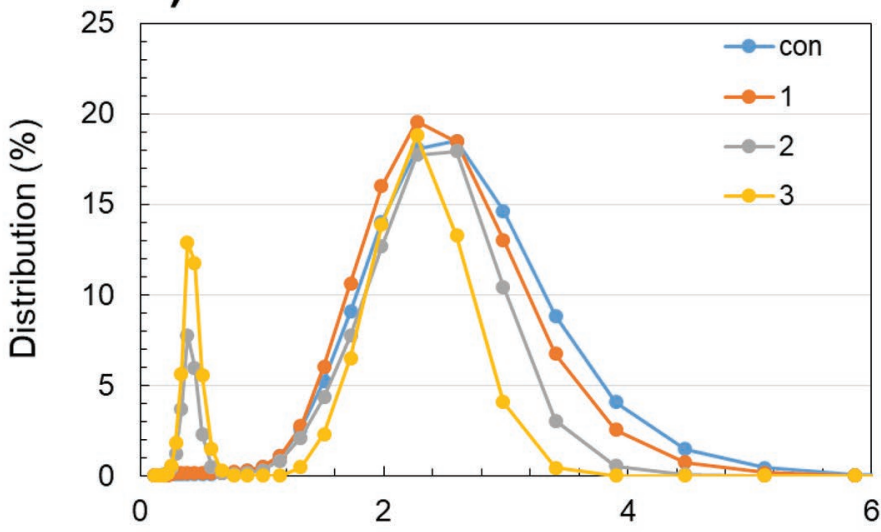

d)

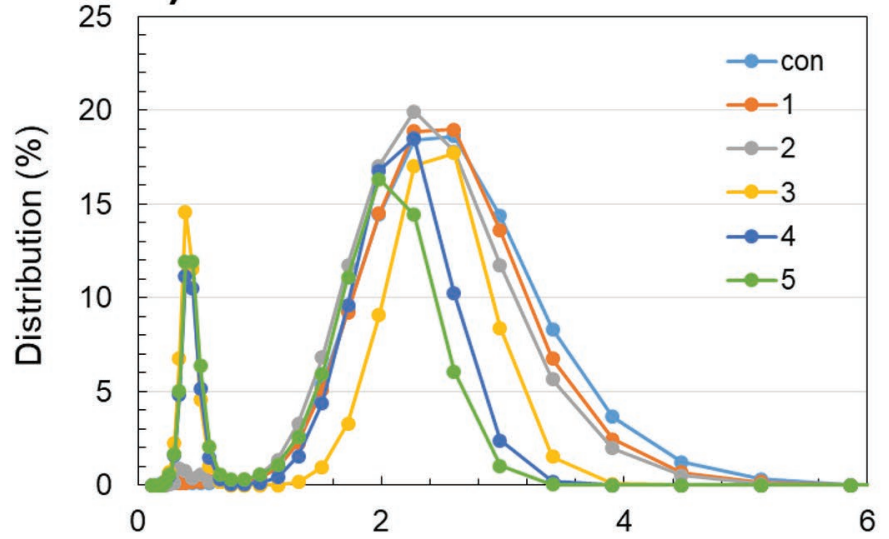

f)

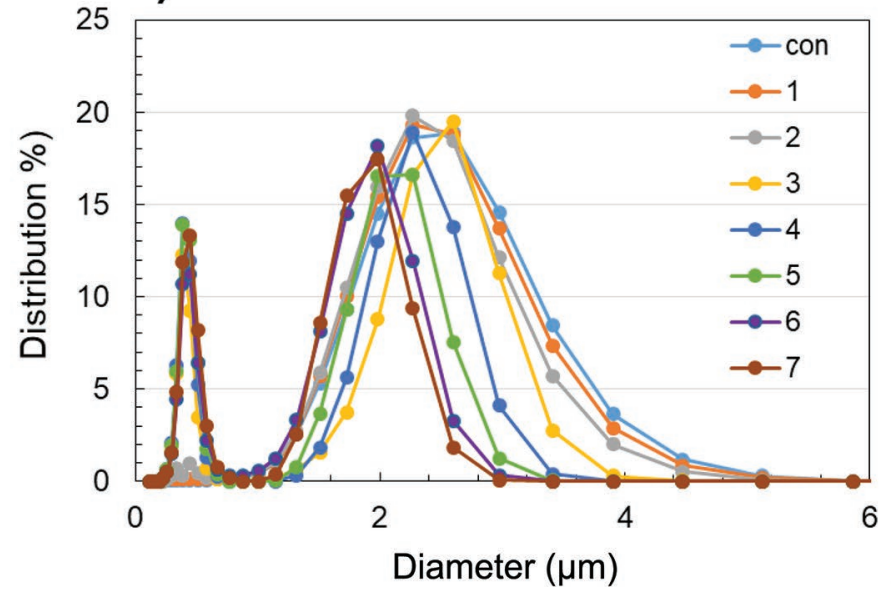

Figure 2. Comparison of volume-weighed particle sizes $(\mathrm{d}[4,3])$ of fat droplets in raw milk controls (con; blue) and milk ultrasonicated at different inlet temperatures and flow rates. Columns, inlet temperatures of milk: left column $(\mathrm{a}, \mathrm{c}, \mathrm{e}), 42^{\circ} \mathrm{C}$; and right column $(\mathrm{b}, \mathrm{d}, \mathrm{f}), 54^{\circ} \mathrm{C}$. Rows, flow rates: top row (a, b), $0.15 \mathrm{~L} / \mathrm{min}$; middle row (c, d), $0.30 \mathrm{~L} / \mathrm{min}$; and bottom row (e, f), $0.45 \mathrm{~L} / \mathrm{min}$. To obtain a total ultrasonication exposure of 18,15 , or 14 min, samples underwent multiple passes; 3,5 , or 7 for flow rates of $0.15,0.30$, or $0.45 \mathrm{~L} / \mathrm{min}$, respectively; passes 1 , orange; 2 , gray; 3 , yellow; 4, dark blue; 5 , green; 6 , purple; and 7 , red. 
a)

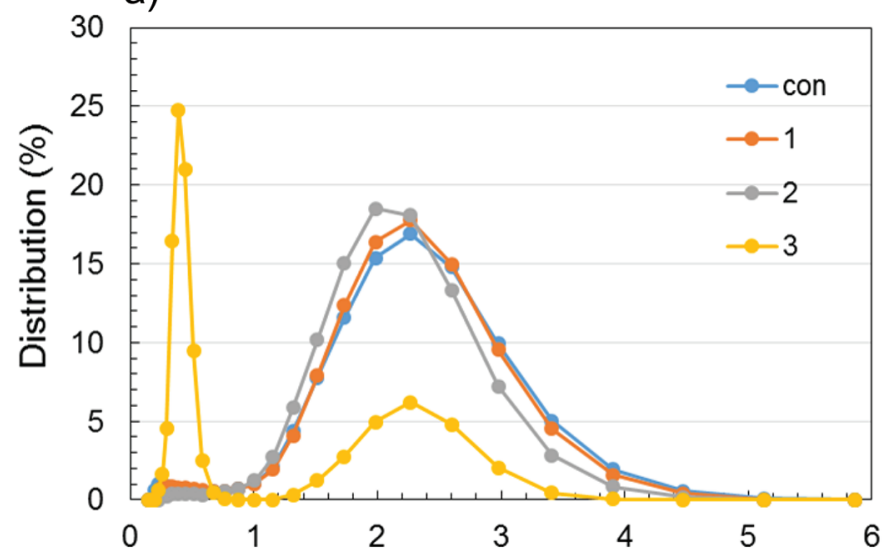

c)

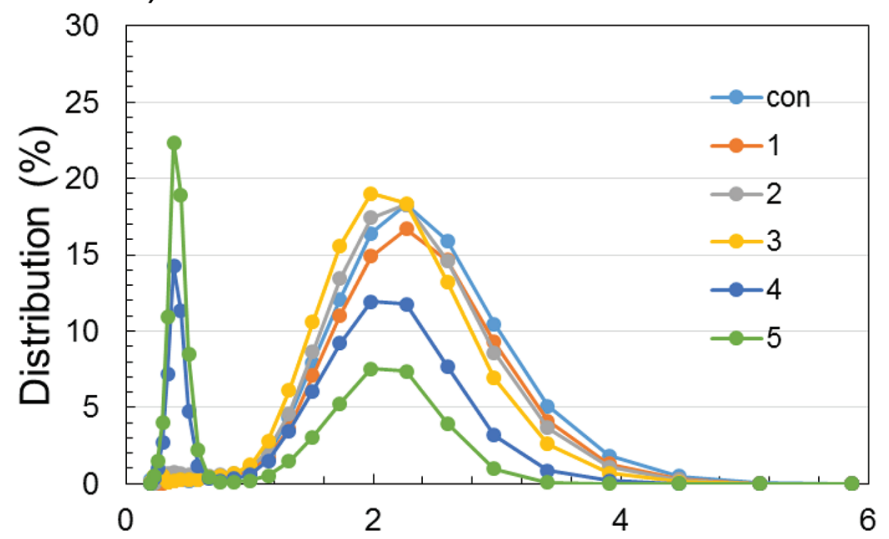

e)

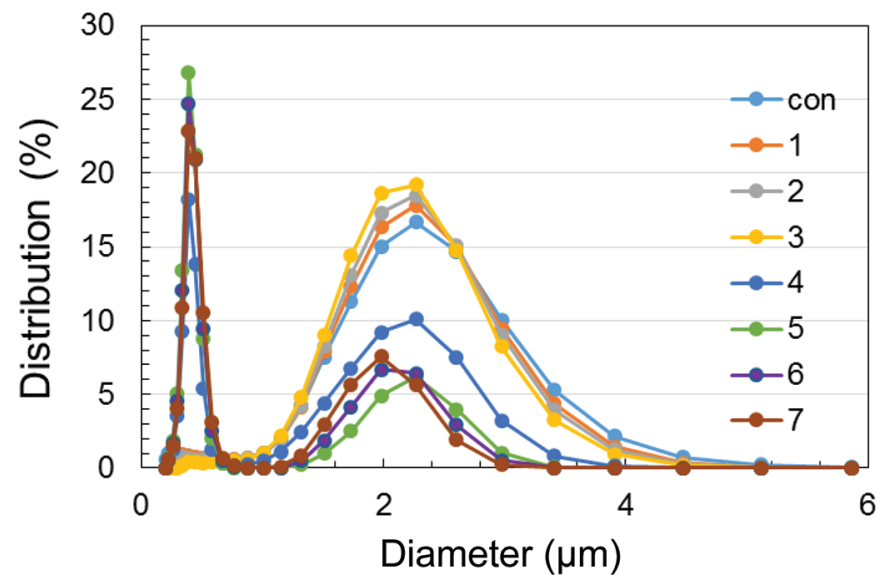

b)

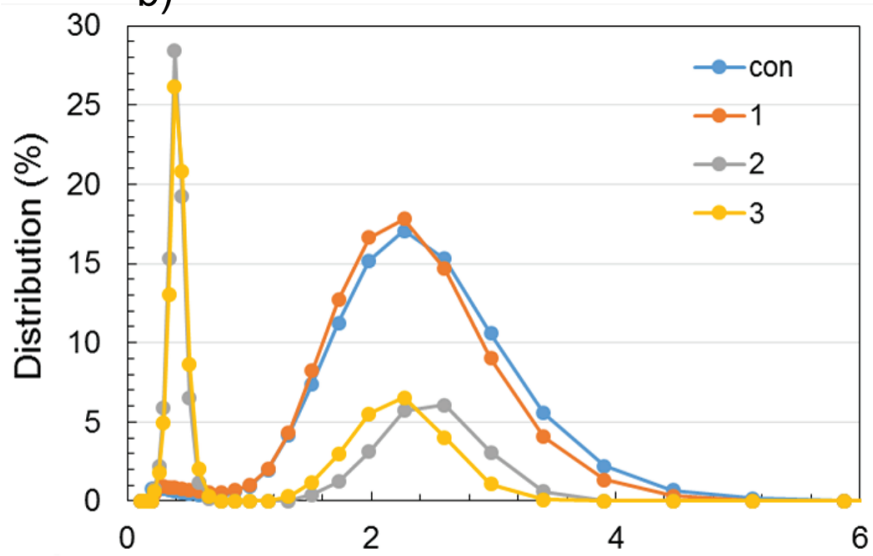

d)

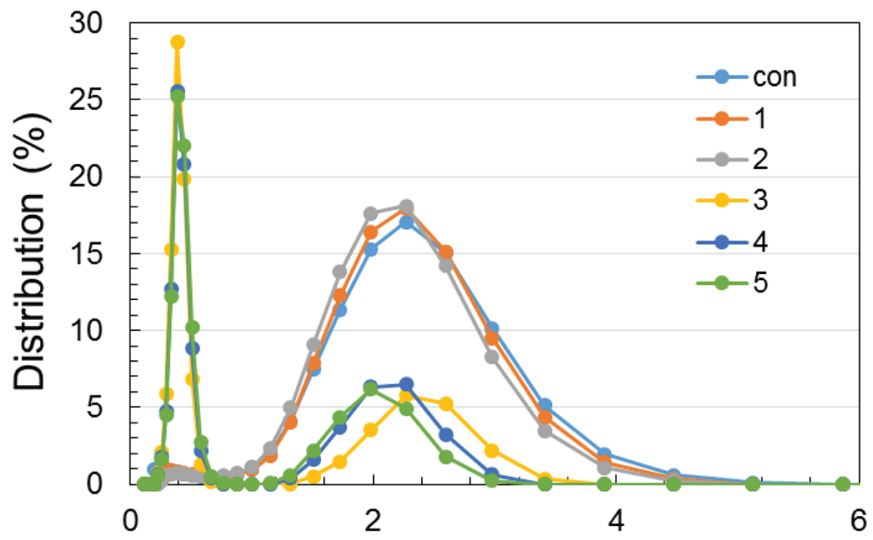

f)

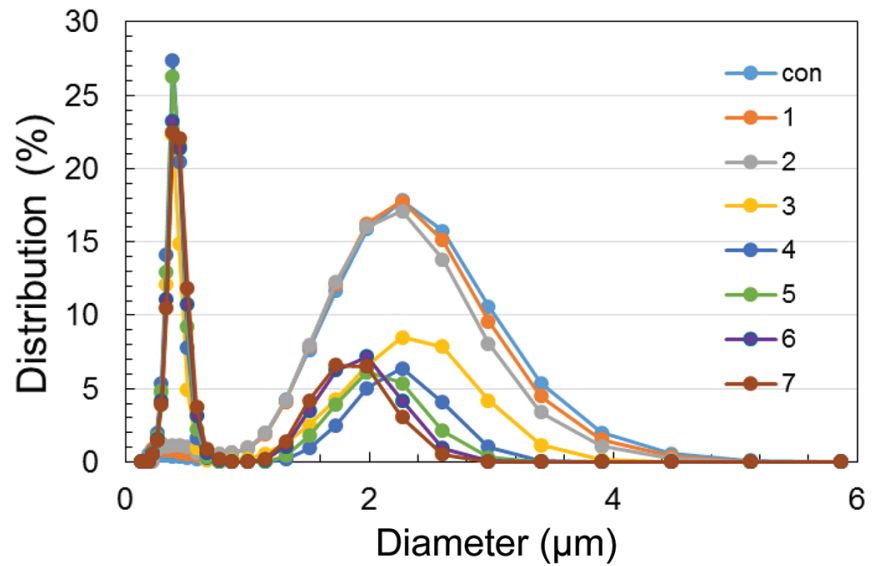

Figure 3. Comparison of area-weighted particle sizes $(\mathrm{d}[3,2])$ of fat droplets in raw milk controls (con; blue) and milk ultrasonicated at different inlet temperatures and flow rates. Columns, inlet temperatures of milk: left column (a, c, e), $42^{\circ} \mathrm{C}$; and right column (b, d, f), $54^{\circ} \mathrm{C}$. Rows, flow rates: top row $(\mathrm{a}, \mathrm{b}), 0.15 \mathrm{~L} / \mathrm{min}$; middle row $(\mathrm{c}, \mathrm{d}), 0.30 \mathrm{~L} / \mathrm{min}$; and bottom row (e, f), $0.45 \mathrm{~L} / \mathrm{min}$. To obtain a total ultrasonication exposure of 18,15 , or 14 min, samples underwent multiple passes; 3,5 , or 7 for flow rates of 0.15 , 0.30 , or $0.45 \mathrm{~L} /$ min, respectively; passes 1 , orange; 2 , gray; 3 , yellow; 4, dark blue; 5 , green; 6 , purple; and 7 , red. 
and 3e) up to exposures of 12,9 , and 6 min for the slowest, medium, and fastest flow rates, respectively, and at $54^{\circ} \mathrm{C}$ (Figure $3 \mathrm{~b}, 3 \mathrm{~d}$, and 3f) up to exposures of 6,6 , and 4 min, respectively. Once the submicron peak appeared, the distribution of the larger peaks decreased from 15 to $18 \%$ down to 5 to $8 \%$, with an exception of $42 \mathrm{~m} 12$ (inlet temperature of $42^{\circ} \mathrm{C}$, medium flow rate, and total US exposure time of $12 \mathrm{~min}$ ). The larger peak did not disappear completely (remained around 5\%) but the diameter continued to decrease. When milk at $42^{\circ} \mathrm{C}$ inlet temperature was processed, the submicron peak was not present after $12 \mathrm{~min}$ at the slowest flow rate but was present by $8 \mathrm{~min}$ at the fastest flow rate. At $54^{\circ} \mathrm{C}$, the submicron peak appeared between 4 and 6 min at the fastest flow rate.
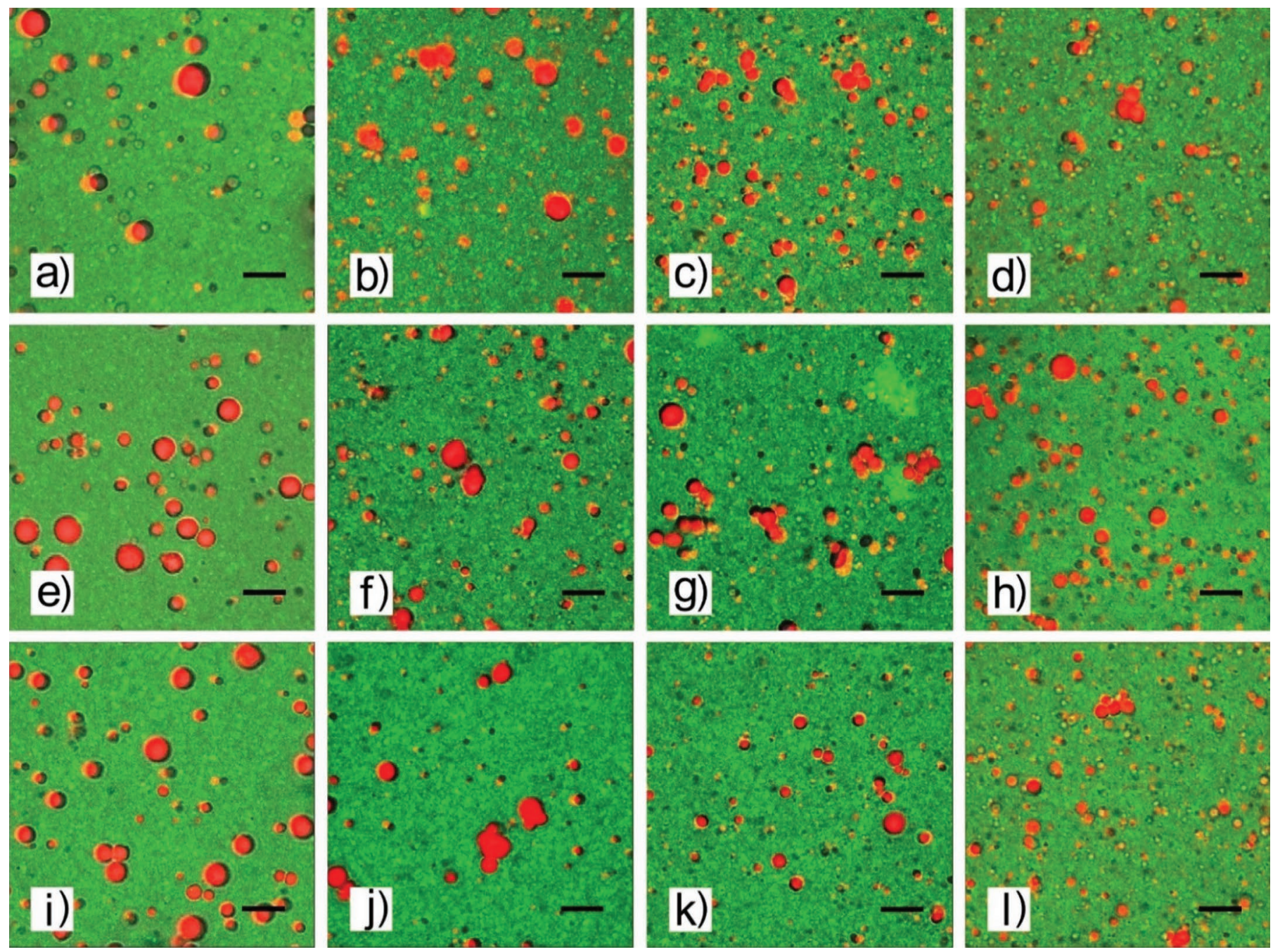

Figure 4. Confocal images of raw milk controls and milk at inlet temperature of $54^{\circ} \mathrm{C}$ ultrasonicated at different flow rates and exposure times. Rows, flow rates: top row (a, b, c, d), $0.15 \mathrm{~L} / \mathrm{min}$; middle row (e, f, g, h), $0.30 \mathrm{~L} / \mathrm{min}$; and bottom row (i, j, k, l), $0.45 \mathrm{~L} / \mathrm{min}$. Column, exposure time: first column (a, e, i), controls; second column (b, f, j), pass before submicron peak appears; third column (c, g, k), pass when submicron peak appears; and fourth column (d, h, l), last pass with maximum exposure time. Scale bar represents $10 \mu \mathrm{m}$. Lipids are stained red and yellow, and protein is stained green. 
a background of protein (stained green). During US processing, the large fat droplets became less frequent as they were fractured into smaller droplets. In the pass before the appearance of the submicron peak, milk samples still contained many large or clustered fat droplets (Figure 4b, 4f, and 4j). After the submicron peak appeared, smaller droplets were plentiful among the medium-sized droplets with larger droplets appearing to be clusters of medium-sized droplets (Figure 4c, $4 \mathrm{~g}$, and $4 \mathrm{k}$ ). After $14 \mathrm{~min}$ of US exposure (Figure 4d, $4 \mathrm{~h}$, and $4 \mathrm{l}$ ), the submicron fat droplets dominated, although medium and smaller particles were still present. Confocal images of US milk with abundant submicronsized fat droplets (Figure 4c, 4d, 4g, 4h, 4k, and 4l) were similar to those of $3 \%$ fat milk homogenized using a 2-stage homogenizer reported by Bucci et al. (2018).

Milk inlet temperature influenced the effectiveness of the US processing. Samples entering the sonication chamber at $42^{\circ} \mathrm{C}$ had larger reductions in diameters and the submicron peak appeared earlier than in samples at inlet temperatures of $54^{\circ} \mathrm{C}$. A similar trend was also noted for flow rate as samples with the fastest flows (shorter bursts of US exposures) had greater reductions in particle diameters. Several studies have shown thermosonication was more effective in homogenizing fat droplets than US alone at lower temperatures (Ertugay et al., 2004; Riener et al., 2009, 2010). The efficient cooling within the US unit lowered the temperature of the milk to below the relatively small range of temperatures near $40^{\circ} \mathrm{C}$, where the milk fat triglycerides transition between liquid and crystalline states. The heat generated within the reaction cell should have raised temperatures somewhat, but it is unknown if it ever exceeded $40^{\circ} \mathrm{C}$. Samples that took 6 min to pass through the reaction cell exited the US unit 5 to $7^{\circ} \mathrm{C}$ cooler than samples taking 2 min per pass (Table 1 ).

Findings from this study suggested that shorter bursts and multiple passes were a more efficient process. The $\mathrm{d}[4.3]$ data also indicated that a minimum US exposure was needed before submicron droplets accumulated enough to be detected. Conditions used in this study had not reduced the fat droplet size below $0.3 \mu \mathrm{m}$, which may reflect a size stability for fat droplets. Although a homogeneous submicron particle size was not reached with the US conditions we tested, the selective nature of acting on the largest of the droplets gives insight into the potential finer control of the microstructure of the cheese matrix in future research.

Unlike microfluidization, another nonthermal processing technique, which creates homogeneous submicron fat droplets in the very first pass through the unit (Bucci et al., 2018), US causes gradual reduction in particle size. Many studies have obtained this homo- geneous submicron emulsion but did so using batch conditions with a transducer tip submerged in the milk for long periods of time. Further testing will determine optimum processing conditions for generating that result in custom-made sized fat droplets for novelty dairy products.

Coagulation Properties. Rennet coagulation of $3 \%$ raw milk was altered by US processing (Figure 5). Ultrasonicated milk that had inlet temperatures of $42^{\circ} \mathrm{C}$ gelled faster and formed firmer curds than the raw milk control or milk that had inlet temperatures of $54^{\circ} \mathrm{C}$. The $42^{\circ} \mathrm{C}$ inlet temperature US-treated milk showed decreased $(P<0.05)$ coagulation times (Figure $5 \mathrm{a})$ and increased curd firmness (Figure 5b) within their first pass, which did not change after repeated US exposure. The samples that had inlet temperatures of $54^{\circ} \mathrm{C}$ and the medium or fastest flow rates also decreased in coagulation time and increased in curd firmness during their first pass, but not to the extent observed for milk that had inlet temperatures of $42^{\circ} \mathrm{C}$. After the second pass, curd firmness decreased, and coagulation times lengthened, appearing similar to nonprocessed control milk after $14 \mathrm{~min}$ of exposure time. Milk entering the US chamber at $54^{\circ} \mathrm{C}$ at the slowest flow rate, increased $(P<0.05)$ in coagulation time, and decreased in curd firmness $(P<0.05)$ as exposure time progressed from 0 to $18 \mathrm{~min}$. All samples showed improved coagulation time at the onset of US, well before a reduction in lipid droplet size was measured. Chymosin-set gels depend on the hydrolysis of the bond between Phe 105 and Met 106 in $\kappa$-casein and a slight decrease in $\mathrm{pH}$ to destabilize the casein micelles before they begin to coalesce (Lucey, 2004). Examination of the control curds microstructure using scanning electron microscopy (Figure 6a and 6e) illustrated the typical matrix made of long continuous protein strands that entrapped large lipid droplets (now void spaces). After 15 min of US exposure, the protein strands are closer together and less continuous. As found with the particle size data, milk receiving 6-min US exposures (Figure $6 \mathrm{~b}$ and $6 \mathrm{f}$ ) was most similar to the controls, whereas samples exposed to 2- and 3-min bursts of US had denser curd matrices (Figure 6d and 6h). Examination of protein strand microstructure using scanning electron microscopy (Figure 7) showed the differences between the raw milk controls (Figure 7a and 7e) and samples after 15 min of US exposure (Figure 7b, 7c, 7d, $7 \mathrm{f}, 7 \mathrm{~g}$, and $7 \mathrm{~h}$ ). Ultrasonicated milk gels showed that smaller lipid droplets acquired a distinct protein layer at their surfaces (arrows) and were embedded within the protein strands of the curd matrix. The degree of lipid insertion within the protein strands gives insight into the change in curd firmness. 
Reduction of curd firmness at higher temperature, with increased US exposure, did not agree with previous studies that reported improved gelation for UStreated milk with homogeneous submicron emulsion stages. Shanmugam et al. (2012) reported that US (20 $\mathrm{kHZ}, 20$ and $41 \mathrm{~W}$ up to $60 \mathrm{~min}, 16^{\circ} \mathrm{C}$ ) processing of pasteurized homogenized skim milk resulted in slight micelle size reduction, possibly because of the removal of the hairy layers, denaturation of whey proteins, and formation of whey-casein aggregates. Nguyen and Anema (2010) reported that US at $22.5 \mathrm{kHz}$ and $50 \mathrm{~W}$ without temperature control reached $>85^{\circ} \mathrm{C}$ within 5 min and $95^{\circ} \mathrm{C}$ by 15 min and showed increased micelle size initially, solubilized $\kappa$-CN from micelles, denatured whey proteins, and whey-casein aggregates. If tempera-
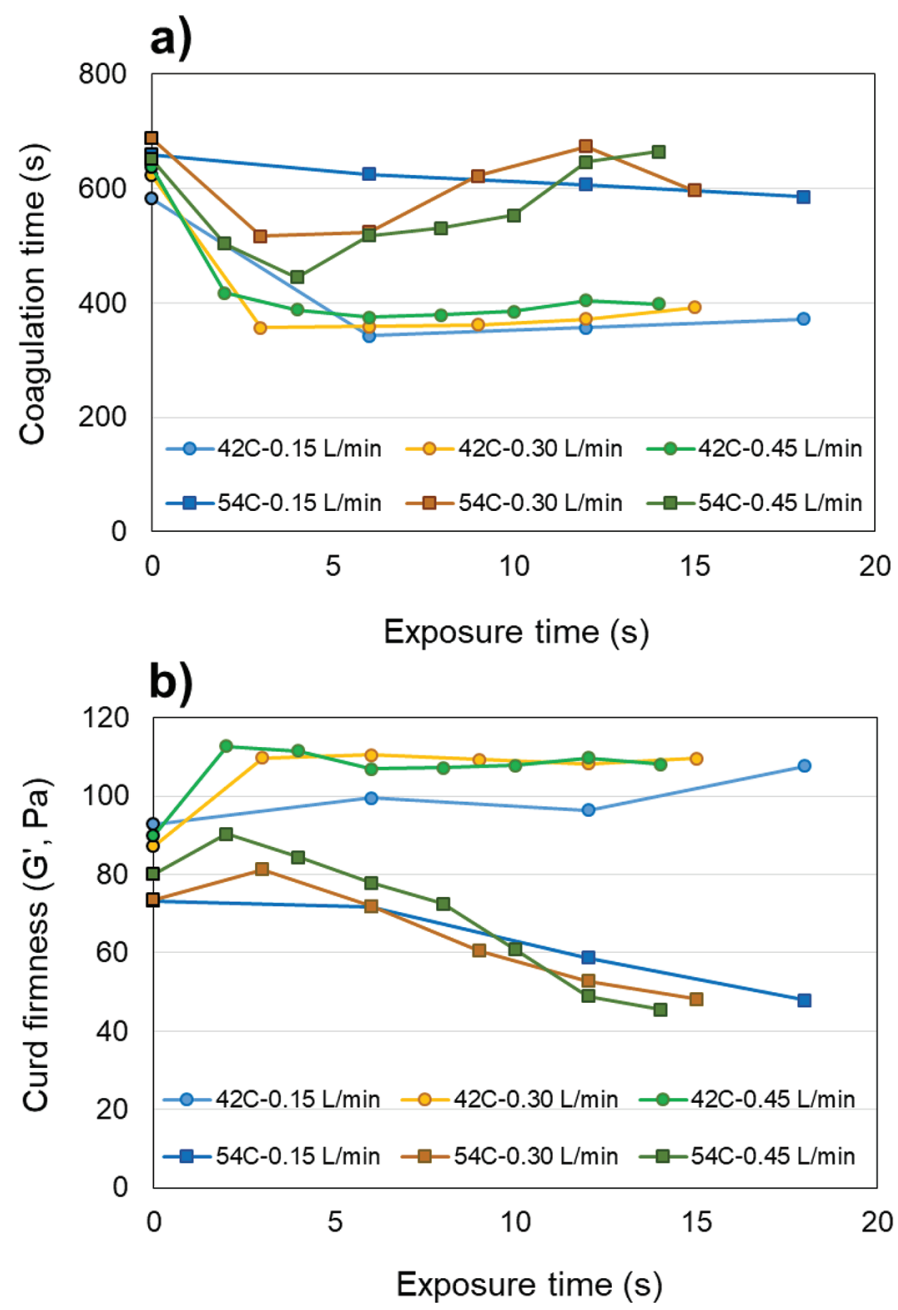

Figure 5. Coagulation properties [(a) coagulation time and (b) curd firmness 30 min after enzyme addition] of raw milk ultrasonicated for up to $18 \mathrm{~min}$ at different processing treatments. Treatments included inlet temperatures of $42^{\circ} \mathrm{C}$ (circles) and $54^{\circ} \mathrm{C}$ (squares) and flow rates of 0.15 (blue), 0.30 (yellow), and 0.45 (green) L/min. tures were controlled, preventing the denaturation of whey proteins, US had minimal effect on making acid gels. Chandrapala et al. (2012a) ultrasonicated skim milk, micellar $\mathrm{CN}$, and $\mathrm{CN}$ powder at $20 \mathrm{kHz}$ and found that after $60 \mathrm{~min}$, there were no changes in micelle size, levels of free $\mathrm{CN}$, or soluble calcium. They concluded that casein was stable when ultrasonicated. Riener et al. (2009) reported that whole milk ultrasonicated for $6 \mathrm{~min}$ at $24 \mathrm{kHz}$ for yogurt making resulted in submicron-sized lipid droplets and had higher curd firmness, water holding capacity, and gelation $\mathrm{pH}$ over normal yogurt-set heated to $90^{\circ} \mathrm{C}$ for $10 \mathrm{~min}$.

Homogenized milk is typically not used to make cheese as the smaller-sized fat droplets result in a short, noncontinuous protein matrix within the curd and poor syneresis properties (Scott, 1986). Queso Fresco is one of the few high-moisture cheeses that use homogenize milk to ensure a crumbly, high-moisture curd that does not melt (Van Hekken et al., 2012). Queso Fresco does have microbial food safety issues (Gould et al., 2014) and wheying off during storage (Van Hekken et al., 2012) that US may be able to address.

Microbiology. Raw milk samples contained $3.81 \pm$ $0.70 \log \mathrm{cfu} / \mathrm{mL}$ of total aerobic mesophilic bacteria, and $2.29 \pm 0.87 \mathrm{log} \mathrm{cfu} / \mathrm{mL}$ of psychrophilic bacteria (Figure $8 \mathrm{a}$, inlet temperature of $42^{\circ} \mathrm{C}$ and $8 \mathrm{~b}$, inlet temperature of $54^{\circ} \mathrm{C}$ ). After standardizing the milk fat concentration, samples were stored for up to $48 \mathrm{~h}$ at $4^{\circ} \mathrm{C}$ before ultrasound processing. During storage, the bacterial counts increased with mesophilic counts between 3.36 and $4.88 \log \mathrm{cfu} / \mathrm{mL}$ (Figure 8, black bars), and psychrophilic counts between 2.59 and $4.35 \log \mathrm{cfu} /$ $\mathrm{mL}$ (Figure 8, white bars). The bacterial load was not affected in most samples by continuous flow ultrasound for milk with inlet temperatures at $42^{\circ} \mathrm{C}$. The exception was a $0.5 \log$ reduction in psychrophilic bacteria at the fastest flow rate (Figure 8a, dotted bars). Milk with inlet temperature of $54^{\circ} \mathrm{C}$ was shown to improve the antimicrobial activity of ultrasound processing, with mesophilic counts reduced by an average of 1.3 and $1.4 \mathrm{log}$ when medium and fastest flow rates were used, respectively (Figure 8, gray bars).

The lack of greater microbial reductions was attributed to US at lower temperatures. These findings were in agreement with previous studies that showed ultrasound processing at temperatures above $50^{\circ} \mathrm{C}$ was effective in eliminating Pseudomonas fluorescens and Streptococcus thermophilius in milk (Villamiel and De Jong, 2000b). In our study, milk with an inlet temperature of $54^{\circ} \mathrm{C}$ was more effective than the $42^{\circ} \mathrm{C}$ inlet temperature in reducing the number of psychrophilic bacteria within raw milk, with counts dropping below the limit of detection ( $1 \mathrm{log} \mathrm{cfu} / \mathrm{mL})$ for all 3 flow rates 

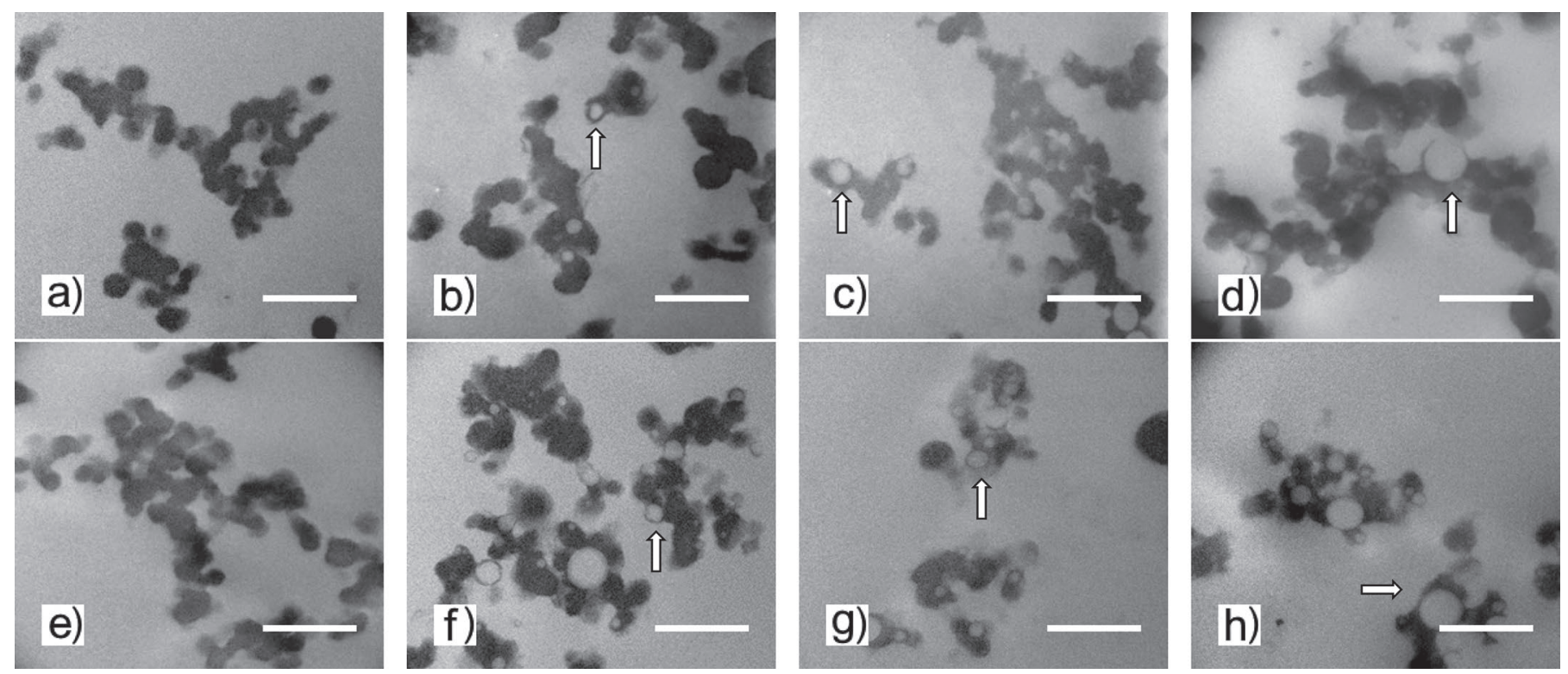

Figure 6. Transmission electron microscopy images of control milk and milk ultrasonicated for the longest exposure times (14 to 18 min) at different inlet temperatures and flow rates. Rows, inlet temperature: top row (a, b, c, d), $42^{\circ} \mathrm{C}$; and bottom row (e, f, g, h), $54^{\circ} \mathrm{C}$. Columns, flow rates: first column (a, e), control; second column (b, f), $0.15 \mathrm{~L} / \mathrm{min}$; third column (c, g), $0.30 \mathrm{~L} / \mathrm{min}$; and fourth column (d, h), $0.45 \mathrm{~L} / \mathrm{min}$. Scale bar represents $0.5 \mu \mathrm{m}$. Arrows point to fat droplets surrounded by dense protein layer.

tested (Figure 8b, dotted bars). Psychrophilic bacteria were expected to be less tolerant of the higher temperatures when compared with mesophilic bacteria, which may explain why the ultrasound treatment was effective against these bacteria, even at the slowest flow rate, which showed approximately $2 \log$ reductions in bacteria after 6 min of US processing. These results support previous findings that ultrasound may be an effective antimicrobial application for reducing the number of spoilage microbes in dairy products, thereby extending shelf life (Cameron et al., 2009; Chouliara et al., 2010).
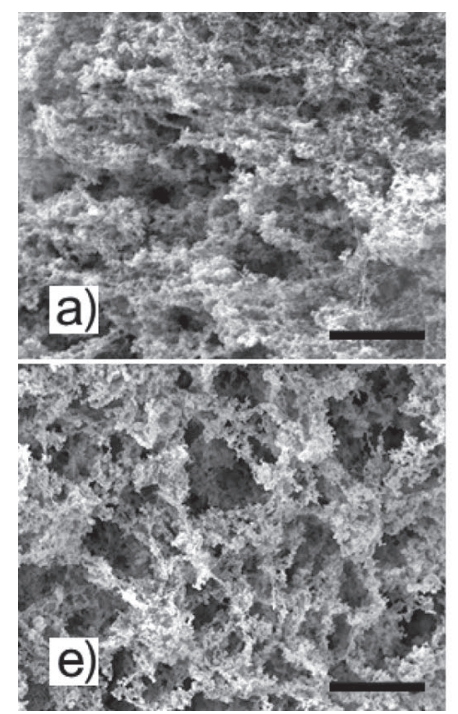
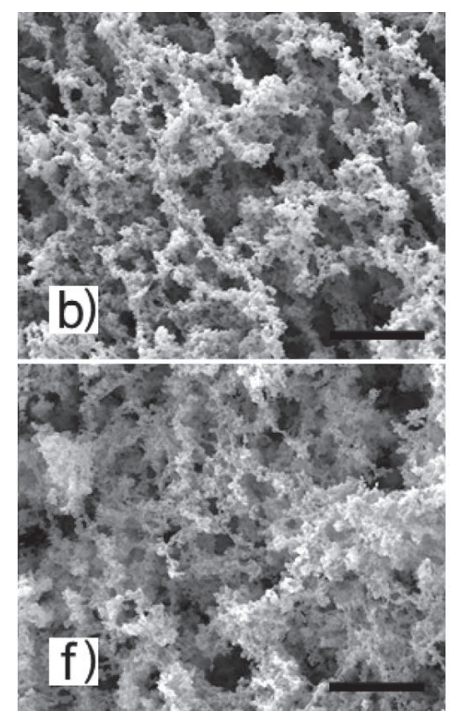
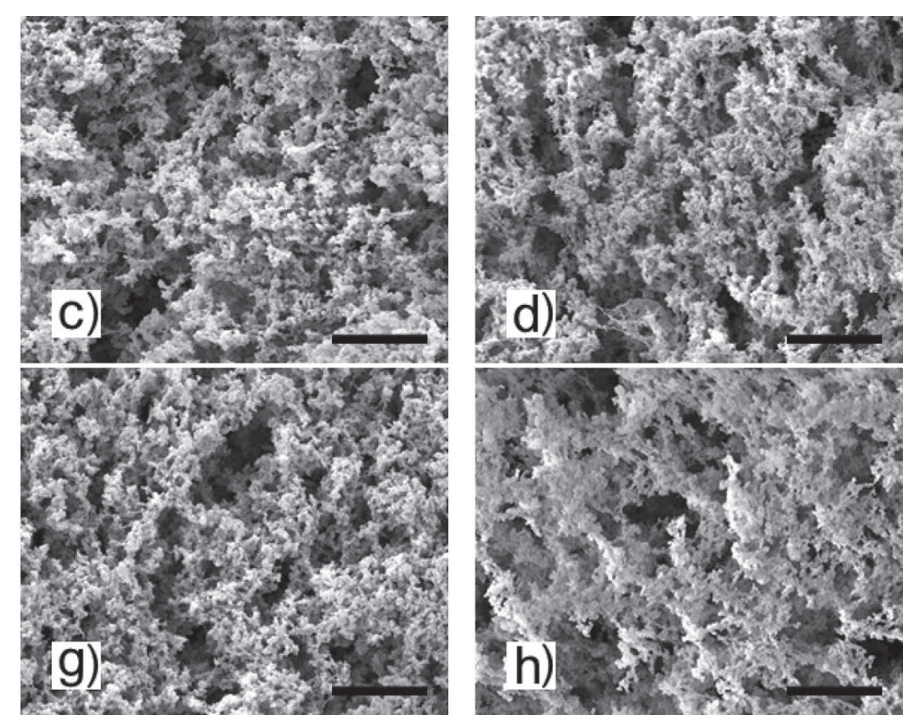

Figure 7. Scanning electron microscopy images of control milk and milk ultrasonicated for the longest exposure times (14 to 18 min) at different inlet temperatures and flow rates. Rows, inlet temperature: top row (a, b, c, d), $42^{\circ} \mathrm{C}$; and bottom row (e, f, g, h), $54^{\circ} \mathrm{C} . \mathrm{Columns}$, flow rates: first column (a, e), control; second column (b, f), $0.15 \mathrm{~L} / \mathrm{min}$; third column (c, g), $0.30 \mathrm{~L} / \mathrm{min}$; and fourth column (d, h), $0.45 \mathrm{~L} / \mathrm{min}$. Scale bar represents $5 \mu \mathrm{m}$. 


\section{Chemical Properties}

Composition. Milk contained $2.91 \pm 0.06 \%$ fat, $3.12 \pm 0.07 \%$ protein, $4.70 \pm 0.11 \%$ lactose, and 11.51 $\pm 0.21 \%$ TS. The slight differences noted after US treatments were not significant. Alkaline phosphatase remained active in all samples after the last pass, indicating that samples were not exposed to pasteurization conditions during the processing run. A faint metalliclike-aroma was present in the US milk that increased in intensity as exposure time accumulated. Current research is underway to identify the undesirable volatile compounds present in our samples. A slight frosting of the metal wall within the reaction cell closest to the transducers suggested cavitation erosion caused by running at $100 \%$ power. Further research at lower power settings may eliminate the aroma. In a review of transducer erosion studies, Mawson et al. (2014) reported that measurable amounts of micron-sized metallic particles were formed by transducer sonotrodes operated at 18 and $20 \mathrm{kHz}$ for $7.5 \mathrm{~h}$. Although amounts were still below acceptable limits for drinking water, further research on sonotrode design or development of food-safe erosion resistance of stainless steel is needed. Other US studies that have reported off-odors that were products of the high heat of cavitation (Riener et al., 2009, 2010) and oxidation of PUFA hydroperoxides (Riener et al., 2009, 2010; Chouliara et al., 2010; Pingret et al., 2013).

Fatty Acid Properties. The fatty acid profiles for the control milk samples were within the accepted ranges reported for bovine milk (Kaylegian and Lindsay, 1995; Jensen, 2002). Although slight differences were present in the individual fatty acid concentrations among the nonprocessed control samples ( $0 \mathrm{~s})$, the majority of fatty acid levels before and after US processing were similar $(P>0.05$; Table 2$)$. With the exception of C18:0, very small changes were detected for C4:0 to $\mathrm{C} 20: 0$ in milk with inlet temperatures of $42^{\circ} \mathrm{C}$ and for C18:0, C14:1, and C18:2 trans,trans in milk with inlet temperatures at $54^{\circ} \mathrm{C}$. Of the $\mathrm{C} 18$ PUFA currently believed to be important in human health, the n-3 linolenic, C18:3, and n-6 linoleic acid, C18:2 cis-9, cis-12 were not altered by US processing. A slight increase occurred in the CLA C18:2 trans,trans following 14 to 18 min of US treatment. Previous studies for longer US periods reported increased levels of pentanal, hexanal, and heptanal, volatiles that indicated oxidation of PUFA (Riener et al., 2009, 2010; Chouliara et al., 2010; Pingret et al., 2013). Results suggested that the 14 to 18 min treatment in our system was not intense enough to induce significant chemical alterations in the fatty acid profile. Further research is suggested.
Although the DSC profiles showed similar $(P>0.05)$ maximum temperature $\left(62.04 \pm 1.45^{\circ} \mathrm{C}\right)$ and enthalpy $(12.57 \pm 0.27 \mathrm{~J} / \mathrm{g})$ among the raw milk controls and US samples, the melt profiles showed a subtle change. Controls (Figure 9a) had the typical milk fat profile with 3 regions, low, medium, and high melt fats separated by

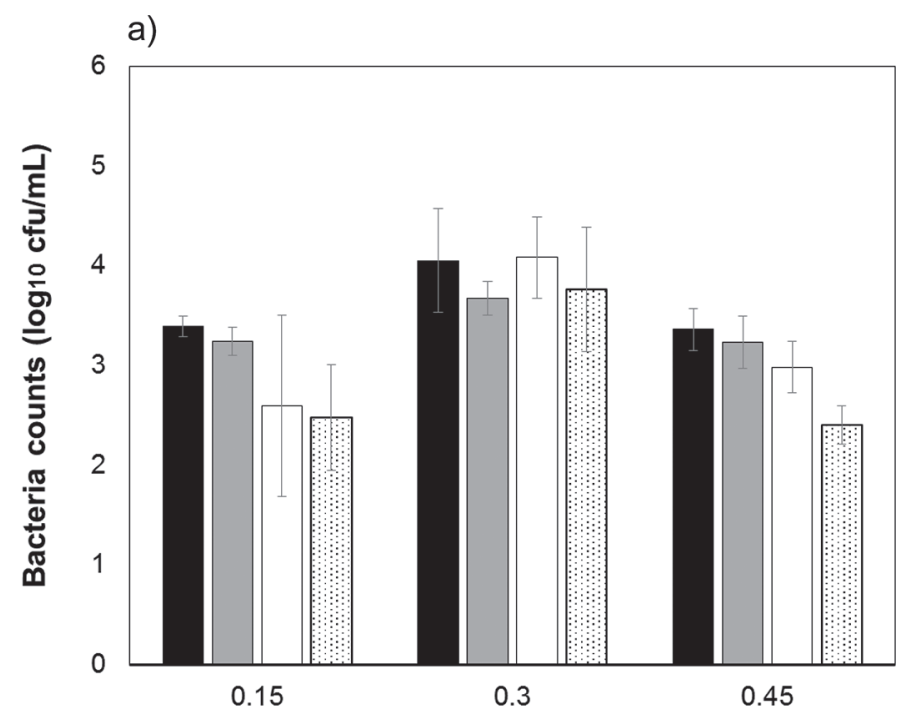

b)

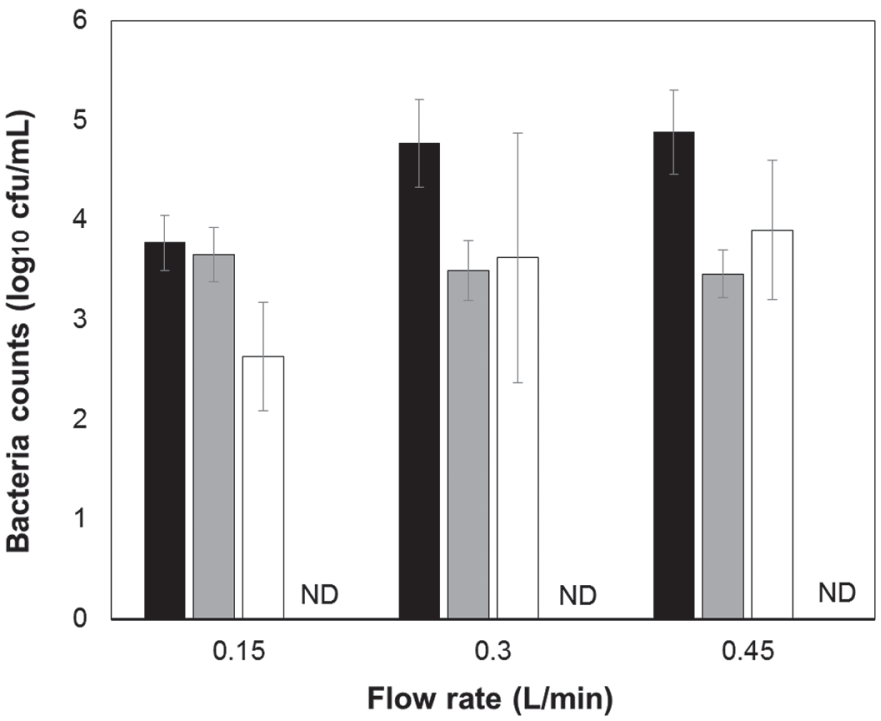

Figure 8. Comparison of the total cell count of indigenous mesophilic and psychrophilic bacteria in raw milk at inlet temperatures of (a) $42^{\circ} \mathrm{C}$ or (b) $54^{\circ} \mathrm{C}$; before (no sonication) and after ultrasonication at different flow rates $(0.15,0.30$, and $0.45 \mathrm{~L} / \mathrm{min})$ for the longest exposure times (14 to $18 \mathrm{~min}$ ). Total mesophilic (control, black bars; and 14 to 18 min of exposure, gray bars) and psychrophilic (control, white bars; and 14 to 18 min of exposure, dotted bars; ND = not detected) bacteria were determined by serial dilution and colony counts on plate count agar. Results are the average of a minimum of 2 independent experiments with SD error bars. 
Table 2. Fatty acid profile of control milk and milk entering the ultrasonication unit at 42 or $54^{\circ} \mathrm{C}$ and sonicated for the longest exposure time of 14 to $18 \mathrm{~min}$, depending on the milk flow rate

\begin{tabular}{|c|c|c|c|c|c|}
\hline \multirow[b]{2}{*}{ Fatty acid } & \multicolumn{2}{|c|}{$42^{\circ} \mathrm{C}$} & \multicolumn{2}{|c|}{$54^{\circ} \mathrm{C}$} & \multirow[b]{2}{*}{ SE } \\
\hline & $0 \mathrm{~s}$ & $14-18 \min$ & $0 \mathrm{~s}$ & $14-18 \min$ & \\
\hline \multicolumn{6}{|l|}{ Saturated } \\
\hline C4:0 & $1.910^{\mathrm{a}}$ & $1.864^{\mathrm{b}}$ & $1.794^{\mathrm{a}}$ & $2.080^{\mathrm{a}}$ & 0.121 \\
\hline $\mathrm{C} 6: 0$ & $1.913^{\mathrm{a}}$ & $1.751^{\mathrm{b}}$ & $1.526^{\mathrm{c}}$ & $1.550^{\mathrm{c}}$ & 0.041 \\
\hline $\mathrm{C} 8: 0$ & $1.307^{\mathrm{a}}$ & $1.220^{\mathrm{b}}$ & $1.083^{\mathrm{c}}$ & $1.100^{\mathrm{c}}$ & 0.022 \\
\hline C10:0 & $3.152^{\mathrm{a}}$ & $3.018^{\mathrm{b}}$ & $2.727^{\mathrm{c}}$ & $2.763^{\mathrm{c}}$ & 0.043 \\
\hline $\mathrm{C} 12: 0$ & $3.604^{\mathrm{a}}$ & $3.516^{\mathrm{a}}$ & $3.267^{\mathrm{c}}$ & $3.292^{\mathrm{c}}$ & 0.356 \\
\hline $\mathrm{C} 13: 0$ & $0.189^{\mathrm{a}}$ & $0.187^{\mathrm{a}}$ & $0.173^{\mathrm{b}}$ & $0.174^{\mathrm{b}}$ & 0.002 \\
\hline C14:0 & $11.93^{\mathrm{a}}$ & $11.88^{\mathrm{a}}$ & $11.38^{\mathrm{b}}$ & $11.54^{\mathrm{b}}$ & 0.073 \\
\hline $\mathrm{C} 15: 0$ & $1.130^{\mathrm{a}}$ & $1.215^{\mathrm{a}}$ & $1.213^{\mathrm{a}}$ & $1.222^{\mathrm{a}}$ & 0.007 \\
\hline C16:0 & $32.87^{\mathrm{b}}$ & $33.28^{\mathrm{a}}$ & $32.10^{\mathrm{c}}$ & $32.04^{\mathrm{c}}$ & 0.145 \\
\hline C17:0 & $0.726^{\mathrm{b}}$ & $0.721^{\mathrm{b}}$ & $0.774^{\mathrm{a}}$ & $0.765^{\mathrm{a}}$ & 0.005 \\
\hline C18:0 & $11.92^{\mathrm{c}}$ & $11.83^{\mathrm{c}}$ & $12.79^{\mathrm{a}}$ & $12.53^{\mathrm{b}}$ & 0.095 \\
\hline $\mathrm{C} 20: 0$ & $0.172^{\mathrm{b}}$ & $0.168^{\mathrm{b}}$ & $0.180^{\mathrm{a}}$ & $0.179^{\mathrm{a}}$ & 0.002 \\
\hline \multicolumn{6}{|l|}{ Monounsaturated } \\
\hline C14:1 trans & $0.220^{\mathrm{b}}$ & $0.222^{\mathrm{b}}$ & $0.228^{\mathrm{a}}$ & $0.229^{\mathrm{a}}$ & 0.001 \\
\hline C14:1 & $0.833^{\mathrm{b}}$ & $0.850^{\mathrm{a}}$ & $0.776^{\mathrm{d}}$ & $0.798^{\mathrm{c}}$ & 0.007 \\
\hline $\mathrm{C} 16: 1$ trans & $0.426^{\mathrm{b}}$ & $0.424^{\mathrm{b}}$ & $0.447^{\mathrm{a}}$ & $0.451^{\mathrm{a}}$ & 0.002 \\
\hline C16:1 & $1.731^{\mathrm{a}}$ & $1.733^{\mathrm{a}}$ & $1.753^{\mathrm{a}}$ & $1.757^{\mathrm{a}}$ & 0.012 \\
\hline $\mathrm{C} 17: 1$ & $0.196^{\mathrm{b}}$ & $0.200^{\mathrm{b}}$ & $0.242^{\mathrm{a}}$ & $0.245^{\mathrm{a}}$ & 0.007 \\
\hline C18:1 cis-9 & $18.94^{\mathrm{b}}$ & $19.24^{\mathrm{b}}$ & $20.38^{\mathrm{a}}$ & $20.40^{\mathrm{a}}$ & 0.187 \\
\hline C18:1 & $0.519^{\mathrm{b}}$ & $0.533^{\mathrm{b}}$ & $0.586^{\mathrm{a}}$ & $0.599^{\mathrm{a}}$ & 0.008 \\
\hline $\mathrm{C} 20: 1$ & $0.177^{\mathrm{b}}$ & $0.171^{\mathrm{c}}$ & $0.191^{\mathrm{a}}$ & $0.188^{\mathrm{a}}$ & 0.002 \\
\hline \multicolumn{6}{|l|}{ Polyunsaturated } \\
\hline C18:2 trans,trans & $0.249^{\mathrm{c}}$ & $0.253^{\mathrm{bc}}$ & $0.257^{\mathrm{b}}$ & $0.265^{\mathrm{a}}$ & 0.002 \\
\hline $\mathrm{C} 18: 2$ cis- 9,12 & $2.120^{\mathrm{a}}$ & $2.104^{\mathrm{a}}$ & $2.153^{\mathrm{a}}$ & $2.151^{\mathrm{a}}$ & 0.026 \\
\hline $\mathrm{C} 18: 3 \alpha$ & $0.348^{\mathrm{b}}$ & $0.344^{\mathrm{b}}$ & $0.365^{\mathrm{a}}$ & $0.367^{\mathrm{a}}$ & 0.004 \\
\hline $\mathrm{C} 20: 4$ & $0.131^{\mathrm{a}}$ & $0.127^{\mathrm{a}}$ & $0.129^{\mathrm{a}}$ & $0.127^{\mathrm{a}}$ & 0.002 \\
\hline
\end{tabular}

${ }^{\mathrm{a}-\mathrm{d}}$ Means that do not share the same letter are significantly different $(P<0.05)$.

inflection points (arrows). The inflection point between medium and high melt fats is minimal, however. As the US exposure increased, this inflection point became deeper (Figure 9b). Although sample preparation for DSC eliminated the structure of the fat droplets, it appeared that the higher melt triglycerides may be easier to separate in low-frequency US-treated milk. It has already been established that high-frequency $(>1 \mathrm{MHz})$ US is capable of fractionating milk fats by the size of the lipid droplets (Leong et al., 2014, 2016).

Although low-frequency US is excellent at making fine emulsions and homogenizing milk fat droplets to a uniform submicron size, this study examined the early effects of US, where submicron particles begin to accumulate and changes to coagulation properties are noted. Further optimization of the system is required to identify conditions for desired modification of milk.

\section{CONCLUSIONS}

Use of a continuous US unit, delivering $1.36 \mathrm{~kW} /$ pass within a $2.4-\mathrm{kW}$ reactor cell with parallel diaphragm plates and 2 transducers $(16 / 20 \mathrm{kHz})$ external to the reactor for milk entering the unit at 42 or $54^{\circ} \mathrm{C}$, resulted in the formation of significant amounts of submicronsized fat droplets and altered the coagulation properties of the milk. Microscopic imaging illustrated the changes in fat droplet sizes in milk and the curd matrix microstructure, which gives insight into the altered protein-lipid and protein-protein interactions within the modified milk. The system also reduced microbial counts at temperatures below pasteurization conditions, although specific activity against bacterial pathogens is needed to validate US as an alternative to thermal processing. Further optimization of the system, including processing milk at temperatures above the melting point of milk fat yet below pasteurization temperature $\left(63^{\circ} \mathrm{C}\right)$, is required; however, the results from this study suggest continuous US may be a suitable tool for dairy food processing.

\section{ACKNOWLEDGMENTS}

The authors thank the following Agricultural Research Service scientists for their contribution to this manuscript: Ray Kwozcak, Susan Iandola, Andre 
a)

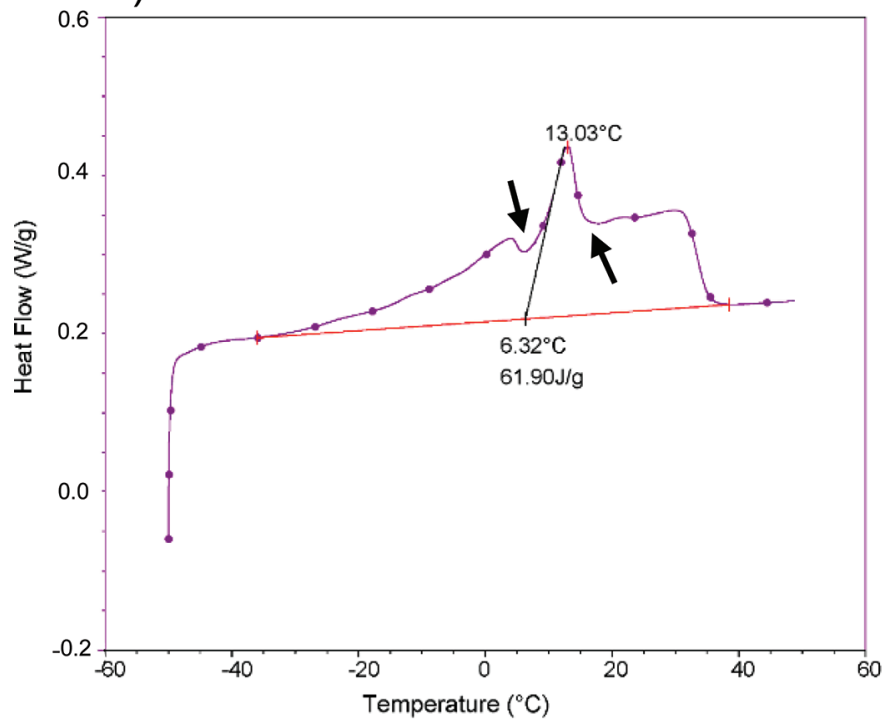

b)

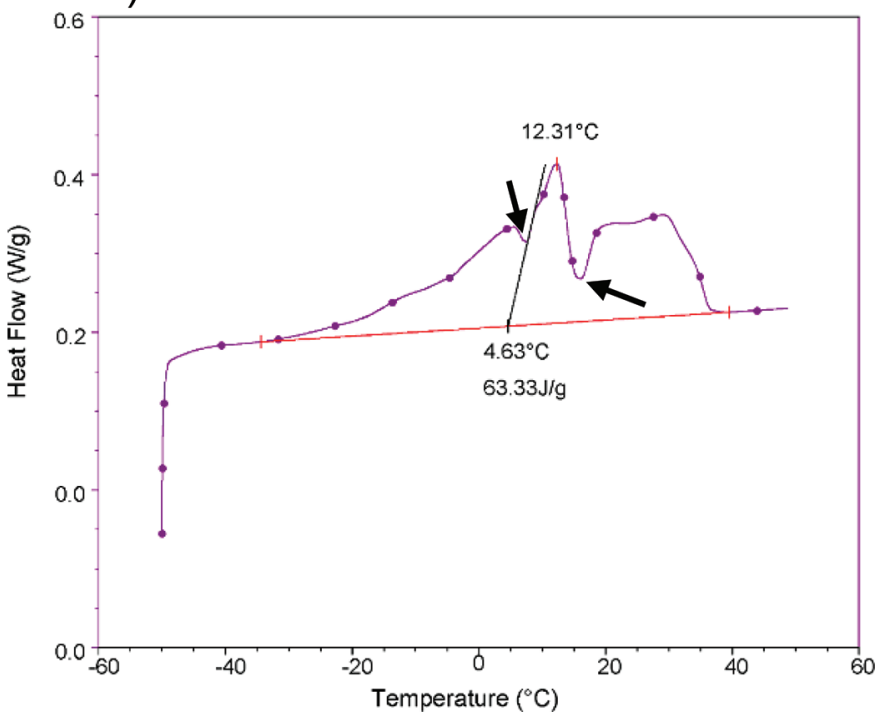

Figure 9. Differential scanning calorimeter profile of (a) typical control and (b) 18-min ultrasonicated milk samples. Arrows indicate the inflection points separating the ranges for low, medium, and high temperature melting fats.

White, Joe Uknalis, Laura Cerro, Ben Fulton, and Ai Vi Truong. Mention of commercial products in this publication is solely for the purpose of providing specific information and does not imply recommendation or endorsement by the US Department of Agriculture. USDA is an equal opportunity provider and employer. This work was supported by the in-house Project 807241000-097-00D, "Effect of Processing of Milk on Bioactive Compounds in Fresh High-Moisture Cheeses."

\section{REFERENCES}

AOAC International. 2012. Official Methods of Analysis. 19th ed. AOAC International, Gaithersburg, MD.

Ashokkumar, M., R. Bhaskaracharya, S. Kentish, J. Lee, M. Palmer, and B. Zisu. 2010. The ultrasonic processing of dairy products An overview. Dairy Sci. Technol. 90:147-168. https://doi.org/10 $.1051 / \mathrm{dst} / 2009044$.

Bucci, A. J., D. L. Van Hekken, M. H. Tunick, J. A. Renye, and P. M. Tomasula. 2018. The effects of microfluidization on the physical, microbial, chemical, and coagulation properties of milk. J. Dairy Sci. 101:6990-7001. https://doi.org/10.3168/jds.2017-13907.

Cameron, M., L. D. Mcmaster, and T. J. Britz. 2009. Impact of ultrasound on dairy spoilage microbes and milk components. Dairy Sci. Technol. 89:83-98. https://doi.org/10.1051/dst/2008037.

Chandrapala, J., G. J. O. Martin, B. Zisu, S. E. Kentish, and M. Ashokkumar. 2012a. The effect of ultrasound on casein micelle integrity. J. Dairy Sci. 95:6882-6890.

Chandrapala, J., C. Oliver, S. Kentish, and M. Ashokkumar. 2012b. Ultrasonics in food processing. Ultrason. Sonochem. 19:975-983. https://doi.org/10.1016/j.ultsonch.2012.01.010.

Chouliara, E., K. G. Georgogianni, N. Kanellopoulou, and M. G. Kontominas. 2010. Effect of ultrasonication on microbiological, chemical and sensory properties of raw, thermized and pasteurized milk. Int. Dairy J. 20:307-313. https://doi.org/10.1016/j.idairyj.2009.12 .006 .

Crudo, D., V. Bosco, G. Cavaglià, S. Mantegna, L. Battaglia, and G. Cravotto. 2014. Process intensification in the food industry: $\mathrm{Hy}-$ drodynamic and acoustic cavitation in fresh milk treatment. Agro Food Ind. Hi-Tech 25:55-59.

Drakopoulou, S., S. Terzakis, M. S. Fountoulakis, D. Mantzavinos, and T. Manios. 2009. Ultrasound-induced inactivation of gramnegative and gram-positive bacteria in secondary treated municipal wastewater. Ultrason. Sonochem. 16:629-634. https://doi.org/ 10.1016/j.ultsonch.2008.11.011.

Earnshaw, R. G., J. Appleyard, and R. M. Hurst. 1995. Understanding physical inactivation processes: combined preservation opportunities using heat, ultrasound and pressure. Int. J. Food Microbiol. $28: 197-219$.

Ertugay, M. F., M. Sengül, and M. Sengül. 2004. Effect of ultrasound treatment on milk homogenization and particle size distribution of fat. Turk. J. Vet. Anim. Sci. 28:303-308.

Feng, H., W. Yang, and T. Hielscher. 2008. Power ultrasound Food Sci. Technol. Int. 14:433-436. https://doi.org/10.1177/ 1082013208098814.

Gallego-Juárez, J. A., and K. F. Graff. 2015. Introduction to power ultrasonics. Pages 1-6 in Power Ultrasonics: Applications of HighIntensity Ultrasound. J. A. Gallego-Juárez and K. F. Graff, ed. Woodhead Publishing, Cambridge, UK.

Gould, L. H., E. Mungai, and C. B. Befravesh. 2014. Outbreaks attributed to cheese: Differences between outbreaks caused by unpasteurized and pasteurized dairy products, United States, 1998-2011. Foodborne Pathog. Dis. 11:545-551. https://doi.org/ 10.1089/fpd.2013.1650.

Jensen, R. G. 2002. The composition of bovine milk lipids: January 1995 to December 2000. J. Dairy Sci. 85:295-350. https://doi.org/ 10.3168/jds.S0022-0302(02)74079-4.

Juliano, P., A. Kutter, L. J. Cheng, P. Swiergon, R. Mawson, and M. A. Augustin. 2011. Enhanced creaming of milk fat globules in milk emulsions by the application of ultrasound and detection by means of optical methods. Ultrason. Sonochem. 18:963-973. https://doi .org/10.1016/j.ultsonch.2011.03.003.

Kaylegian, K. E., and R. C. Lindsay. 1995. Milk fat usage and modification. Pages 1-18 in Handbook of Milkfat Fractionation Technology and Application. Am. Oil Chem. Soc. Press, Champaign, IL.

Leong, T., L. Johansson, R. Mawson, S. L. Mcarthur, R. Manasseh, and P. Juliano. 2016. Ultrasonically enhanced fractionation of milk fat in a litre-scale prototype vessel. Ultrason. Sonochem. 28:118 129. https://doi.org/10.1016/j.ultsonch.2015.06.023. 
Leong, T., P. Juliano, L. Johansson, R. Mawson, S. L. Mcarthur, and R. Manasseh. 2014. Temperature effects on the ultrasonic separation of fat from natural whole milk. Ultrason. Sonochem. 21:20922098. https://doi.org/10.1016/j.ultsonch.2014.02.003.

Liu, Z., P. Juliano, R. P. W. Williams, J. Niere, and M. A. Augustin. 2014. Ultrasound improves the renneting properties of milk. Ultrason. Sonochem. 21:2131-2137. https://doi.org/10.1016/j.ultsonch .2014.03.034.

Lucey, J. A. 2004. Cultured dairy products: An overview of their gelation and texture properties. Int. J. Dairy Technol. 57:77-84. https: //doi.org/10.1111/j.1471-0307.2004.00142.x.

Marchesini, G., S. Balzan, F. Montemurro, L. Fasolato, I. Andrighetto, S. Segato, and E. Novelli. 2012. Effect of ultrasound alone or ultrasound coupled with $\mathrm{CO}_{2}$ on the chemical composition, cheesemaking properties and sensory traits of raw milk. Innov. Food Sci. Emerg. Technol. 16:391-397. https://doi.org/10.1016/j.ifset.2012 .09 .003 .

Mawson, R., M. Rout, G. Ripoll, P. Swiergon, T. Signh, K. Knoerzer, and P. Juliano. 2014. Production of particulates from transducer erosion: Implications on food safety. Ultrason. Sonochem. $21: 2122-2130$.

Mortazavi, A., and F. Tabatabaie. 2008. Study of ice cream freezing process after treatment with ultrasound. World Appl. Sci. J. 4:188-190.

Nguyen, N. H., and S. G. Anema. 2010. Effect of ultrasonication on the properties of skim milk used in the formation of acid gels. Innov. Food Sci. Emerg. Technol. 11:616-622. https://doi.org/10.1016/j .ifset.2010.05.006.

Pingret, D., A.-S. Fabiano-Tixier, and F. Chemat. 2013. Degradation during application of ultrasound in food processing: A review. Food Control 31:593-606. https://doi.org/10.1016/j.foodcont.2012 .11.039.

Riener, J., F. Noci, D. A. Cronin, D. J. Morgan, and J. G. Lyng. 2009. The effect of thermosonication of milk on selected physicochemical and microstructural properties of yoghurt gels during fermentation. Food Chem. 114:905-911. https://doi.org/10.1016/j foodchem.2008.10.037.

Riener, J., F. Noci, D. A. Cronin, D. J. Morgan, and J. G. Lyng 2010. A comparison of selected quality characteristics of yoghurts prepared from thermosonicated and conventionally heated milks. Food Chem. 119:1108-1113. https://doi.org/10.1016/j.foodchem .2009.08.025.

Scott, R. 1986. Cheesemaking operations. Pages 186-212 in Cheesemaking Practice. 2nd ed. Elsevier Applied Science Publishers, London, UK.

Shanmugam, A., J. Chandrapala, and M. Ashokkumar. 2012. The effect of ultrasound on the physical and functional properties of skim milk. Innov. Food Sci. Emerg. Technol. 16:251-258. https://doi .org/10.1016/j.ifset.2012.06.005.

Tunick, M. H., and E. L. Malin. 1997. Differential scanning calorimetry of water buffalo and cow milk fat in mozzarella cheese. J. Am.
Oil Chem. Soc. 74:1565-1568. https://doi.org/10.1007/s11746-997 $-0078-0$.

Tunick, M. H., D. X. Ren, D. L. Van Hekken, L. Bonnaillie, M. Paul, R. Kwoczak, and P. M. Tomasula. 2016. Effect of heat and homogenization on in vitro digestion of milk. J. Dairy Sci. 99:4124-4139. https://doi.org/10.3168/jds.2015-10474.

Tunick, M. H., and D. L. Van Hekken. 2017. Fatty acid profiles of in vitro digested processed milk. Foods 6:99-106. https://doi.org/10 $.3390 /$ foods6110099

Van Hekken, D. L., M. H. Tunick, L. N. Leggett, and P. M. Tomasula. 2012. Impact of curd milling on the chemical, functional, and rheological properties of starter-free Queso Fresco. J. Dairy Sci. 95:5527-5535. https://doi.org/10.3168/jds.2011-4933.

Villamiel, M., and P. De Jong. 2000a. Influence of high-intensity ultrasound and heat treatment in continuous flow on fat, proteins, and native enzymes of milk. J. Agric. Food Chem. 48:472-478. https:/ /doi.org/10.1021/jf990181s.

Villamiel, M., and P. De Jong. 2000b. Inactivation of Pseudomonas fluorescens and Streptococcus thermophilus in Trypticase Soy Broth and total bacteria in milk by continuous-flow ultrasonic treatment and conventional heating. J. Food Eng. 45:171-179. https://doi .org/10.1016/S0260-8774(00)00059-5.

Villamiel, M., R. Verdurmen, and P. de Jong. 2000. Degassing of milk by high-intensity ultrasound. Milchwissenschaft 55:123-125.

Wu, H., G. J. Hulbert, and J. R. Mount. 2001. Effects of ultrasound on milk homogenization and fermentation with yogurt starter. Innov. Food Sci. Emerg. Technol. 1:211-218.

Yanjun, S., C. Jianhang, Z. Shuwen, H. Li, L. Jing, L. Lu, H. Uluko, S. Yanling, C. Wenming, G. Wupeng, and L. Jiaping. 2014. Effect of power ultrasound pre-treatment on the physical and functional properties of reconstituted milk protein concentrate. J. Food Eng. 124:11-18. https://doi.org/10.1016/j.jfoodeng.2013.09.013.

Zisu, B., R. Bhaskaracharya, S. Kentish, and M. Ashokkumar. 2010 Ultrasonic processing of dairy systems in large scale reactors. Ultrason. Sonochem. 17:1075-1081. https://doi.org/10.1016/j .ultsonch.2009.10.014.

Zisu, B., and J. Chandrapala. 2015. High Power Ultrasound Processing in Milk and Dairy Products. Pages 149-179 in Emerging Dairy Processing Technologies: Opportunities for the Dairy Industry. N. Datta and P. M. Tomasula, ed. John Wiley \& Sons, Ltd., Chichester, UK.

Zisu, B., J. Lee, J. Chandrapala, R. Bhaskaracharya, M. Palmer, S. Kentish, and M. Ashokkumar. 2011. Effect of ultrasound on the physical and functional properties of reconstituted whey protein powders. J. Dairy Res. 78:226-232. https://doi.org/10.1017/ S0022029911000070

Zisu, B., M. Schleyer, and J. Chandrapala. 2013. Application of ultrasound to reduce viscosity and control the rate of age thickening of concentrated skim milk. Int. Dairy J. 31:41-43. https://doi.org/10 .1016/j.idairyj.2012.04.007. 